\title{
Trends and Future Directions in Crop Energy Analyses: A Focus on Iran
}

\author{
Narges Banaeian ${ }^{1, *(\mathbb{D})}$, Morteza Zangeneh ${ }^{1}(\mathbb{D})$ and Sean Clark $^{2}(\mathbb{D}$ \\ 1 Department of Agricultural Mechanization Engineering, Faculty of Agricultural Sciences, \\ University of Guilan, Rasht 4199613776, Iran; zanganeh@guilan.ac.ir \\ 2 Department of Agriculture and Natural Resources, Berea College, Berea, KY 40404, USA; \\ clarks@berea.edu \\ * Correspondence: banaeian@guilan.ac.ir; Tel.: +98-918-0195190
}

Received: 14 September 2020; Accepted: 27 November 2020; Published: 30 November 2020

\begin{abstract}
This systematic review critically analyzes the literature on the study of energy-use patterns in agricultural crop systems in Iran. We examine the relevant methodologies and research trends from 2008 to 2019 , a particularly active and productive period. Initially, we find researchers using energy audits and regression modeling to estimate energy-use patterns. Then economic and environmental-emissions audits are more commonly incorporated into analyses. Finally, the application of different Artificial Intelligence (AI) methods are observed in papers. The main focus of this study is on energy-use patterns, economic modelling, and environmental emissions. We then address critical issues, including sample size, energy equivalents, and additional practical energy-saving recommendations which can be considered by researchers in future analyses. The application of AI in the analysis of agricultural systems, and how it can be used to achieve sustainable agriculture, is discussed with the aim of providing guidelines for researchers interested in energy flow in agricultural systems, especially in Iran. To achieve sustainable agriculture systems, we recommend more attention be given toward considering the impact of social factors in addition to energy, environmental and economic factors. Finally, this review should guide other researchers in choosing appropriate crop types and regions in need study to avoid repetitive studies.
\end{abstract}

Keywords: energy; environmental and economic assessment; agricultural systems; sustainability

\section{Introduction}

\subsection{Rationale of the Review}

Global human population growth and a lack of sufficient land to produce food necessitates more intensive crop production practices [1]. The main driver for intensive agriculture is energy, a limited resource. Moreover, increasing energy consumption in agriculture results in more Greenhouse Gas (GHG) emissions and accelerated global climate change (farming accounts for about $10-12 \%$ of all human-made GHG emissions) [2]. More efficient consumption of energy in agroecosystems will therefore increase energy security, decrease environmental impacts and degradation of natural resources, and help to direct agricultural systems to be more consistent with and supportive of sustainable development policies [3]. The first step in addressing this challenge is understanding the current patterns of energy consumption in agricultural systems, in order to develop possible approaches for minimizing energy consumption and the associated negative environmental impacts. The logic of this review study is to report the research methodologies, address their challenges and indicate a summary of the results obtained in researches conducted in different crops and regions of Iran. Researchers who are interested in this field can benefit by conducting new research by achieving 
a proper understanding of the research background provided here, particularly by finding neglected research needs which are not being met. The primary studies on the pattern of energy consumption in the agricultural sector began in 2008 in Iran. The cheapness of energy resources and the allocation of government subsidies to energy in the agricultural sector had caused energy consumption in this sector to grow further. The entry of researchers into the subject of monitoring energy consumption and comparing the pattern of energy consumption in different products and regions was a good start on energy consumption management in the agricultural sector of Iran. After the implementation of the law on subsidies in 2010 and the increase in the price of energy carriers in Iran, government officials and farmers became aware of the importance of examining the pattern of energy consumption on farms. Comparing the patterns of energy consumption in different farms and how to model successful farms in reducing energy consumption by keeping the amount of crop production constant became very attractive among farmers. By realizing energy prices in Iran has led to a large increase in the number of studies on energy consumption patterns. Therefore, in order to properly direct future research, it is necessary for researchers to have sufficient information about the results of previous studies in this field. In this study, a significant number of energy studies in the agricultural sector of Iran have been reviewed. Studying this article can provide readers and researchers with a comprehensive understanding and picture of the energy consumption pattern and how to conduct new energy consumption pattern studies.

\subsection{Objectives}

Articles published in this field have evolved in recent years. These studies are actually part of the system analysis process. In this evolution, first, the pattern of energy consumption was examined using simple indicators. Gradually, other dimensions of agricultural systems entered the analysis, such as the economic modelling and environmental emissions modelling. The methodologies used by researchers gradually diversified and artificial intelligence methods were introduced into the methodologies. The first question we seek to answer in this study is whether, despite the wide variety of indicators and methods used by previous researchers, all aspects of a crop production system are fully explored or are there still other aspects that researchers neglected them? Another question that we sought to answer in this study is have the necessary standards for sampling been met? From the point of view of system analysis, studying the current situation without interventions to improve the system is considered incomplete. Has any intervention been made in the studies to improve the situation of energy consumption pattern or reduce environmental emissions and improve the economic model? Another important question is whether hypotheses have been made about the reasons for the formation of current patterns in energy, economics and the environment in such studies? Are remedial strategies suggested in the studies? Have social indicators been examined in the analysis of energy consumption pattern, environment and economy? In part of this review study, the correlation between the number of articles published in different crops and the amount of production of those crops is shown, which can be a good indicator to understand the importance of conducting research in each area. This study can prevent duplicate research, which has been observed in some, and provide researchers with a new way to complete studies in this field. Finding the answers to these questions by reviewing the studies conducted in this field can help the development and maturity of more research in this field.

\section{Methods}

\subsection{Protocol of the Review}

In our search strategy, keywords frequently used in this type of articles were used to find articles related to energy consumption pattern. Keywords that are most common in this type of articles are: energy, energy ratio, Iran, product name (e.g., wheat, barley and etc.), economic analysis; energy efficiency, energy analysis, input energy, environment, technical efficiency, data envelopment analysis, energy saving, life cycle assessment, yield, energy use pattern, crop systems, environmental 
emissions, artificial neural networks, genetic algorithm, sensitivity analysis and so on. The systematic review process is shown in Figure 1.

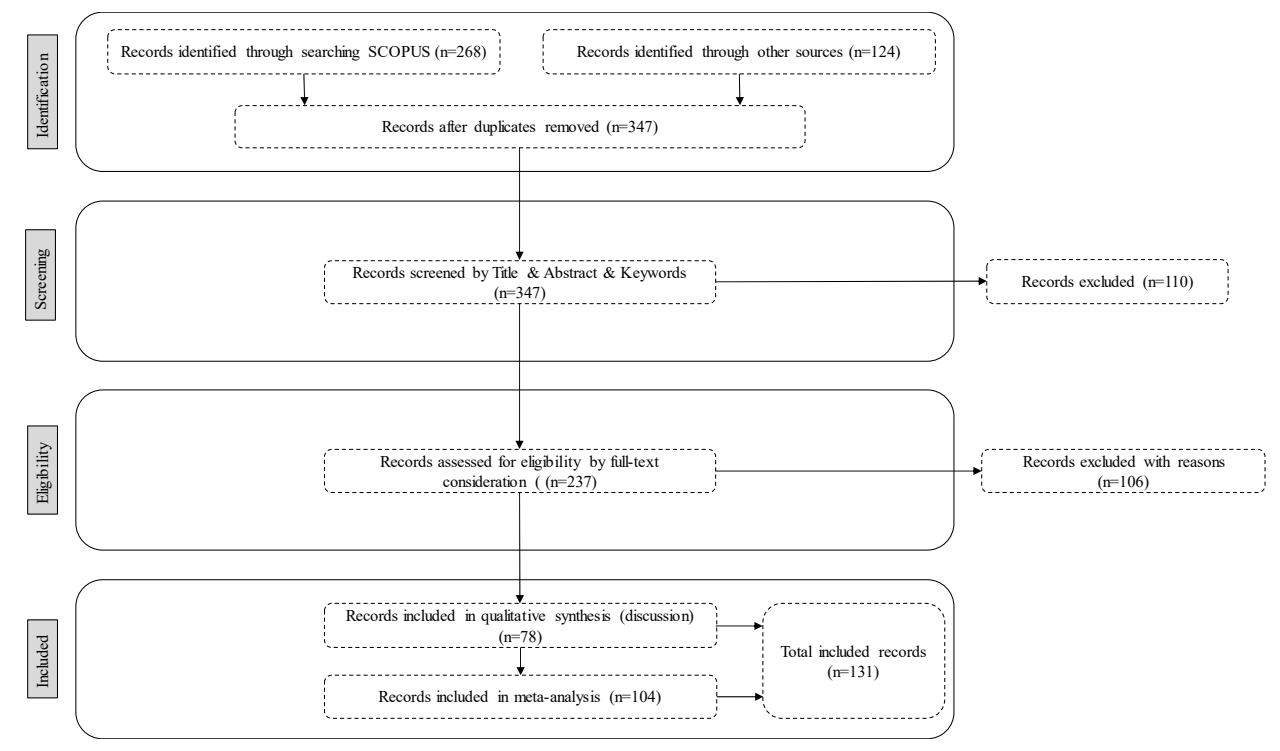

Figure 1. Systematic review process used in this study.

\subsection{Eligibility Criteria}

Finding suitable articles for review in this study was based on several criteria. The subject of the article was the first criteria, the relevance of which was done through search using a large number of common keywords in this field of research. The next criteria was the location of the research. Since the focus of the present study is on Iran, only articles done in Iran were selected. Articles in the field of energy in agricultural systems are basically case studies, so it was easier to find suitable cases according to the names of the areas mentioned in the articles. The quality of the journals in which articles were published was another indicator that was considered. Articles published in reputable journals were selected, and a number of articles published in unreliable journals were excluded from the selection cycle to avoid compromising the validity of the results.

\subsection{Information Sources}

The Scopus database was used as the main source to search for articles. Other scientific databases that release articles such as Google Scholar, Research Gate, etc. were also used.

\subsection{Study Selection}

By searching frequently used keywords in the article titles, article abstract and keywords, 268 articles were identified in the Scopus database. While, 124 articles were obtained by reviewing other databases. After reviewing duplicate articles, it was found that 47 articles were common to both search methods and were deleted. In the next step, the title, abstract and keywords of 347 records were examined. In total, 110 records were discarded as they were not included in the scope of energy studies in the agricultural sector of Iran. The full text of 237 articles was studied and by reviewing them, it was determined that 106 articles should be removed from the review process for the following reasons: Articles published in unreliable journals, articles studying greenhouse or horticultural products, articles published by the same team of authors with the overlap. At the end of this process, 131 articles remained that were reviewed in this study. In these articles, 21 types of crops have been studied. Articles are selected from 2008 to 2019. In the search process, only articles published in English were considered. Short papers, conference papers published in proceedings, and book chapters were also excluded from the review process. 


\subsection{Data Collection Process}

The main purpose of this article is to review the methods used in the analysis of agricultural systems in Iran, so data collection from articles is of secondary importance. However, in part of this article, a summary of the results reported in the articles is given. For this purpose, the tables of published articles were used.

\subsection{Data Items}

To create an overview of the state of energy consumption pattern in Iranian agricultural products, three important indicators were examined: Total energy input, energy use efficiency and net energy. The average status of these indicators was extracted and reported.

\subsection{Risk of Bias in Individual Studies}

In this section we describe methods used for assessing risk of bias of individual studies (including specification of whether this was done at the study or outcome level), and how this information is to be used in any data synthesis. To overcome the risk of bias that may affect the cumulative evidence, we used the average of results (e.g., Total Energy Input (TEI) \& Energy Use Efficiency (EUE)) reported in papers for same crops.

\subsubsection{Sampling Methods}

Almost all energy studies have used static surveys. These studies usually use a sample-size calculation method and a sampling method to determine the number of sample cases. The main sampling method used in these studies is random sampling. Two sample-size calculation methods are commonly used in studies, Cochran and Neyman methods which are calculated as [4,5] (Equations (1) and (2)),

$$
n=\frac{N(s \times t)^{2}}{(N-1) d^{2}+(s \times t)^{2}}
$$

where $n$ is the required sample size, $N$ is the number of farms in the target population, $t$ is the reliability coefficient (1.96 which represent $95 \%$ confidence), $s$ is the standard deviation of pre-tested data, and $d$ is the precision or acceptance error which is defined to be $5 \%$ for a confidence level of $95 \%$. While,

$$
n=\frac{\sum N_{h} S_{h}}{N^{2} D^{2}+\sum N_{h} S_{h}^{2}}
$$

where $n$ is required sample size, $N$ is the number of all farms in the target population, $N_{h}$ is the number of the population in the $\mathrm{h}$ stratification, $S_{h}$ is the standard deviation in the $\mathrm{h}$ stratification, $S_{h}^{2}$ is the variance of $h$ stratification, $D$ is the precision $(x-X)$ and $D^{2}=d^{2} / z^{2}$, and $z$ is the reliability coefficient (1.96 which represents the $95 \%$ reliability).

\subsubsection{Risks and Challenges of Sampling}

Due to the wide variety of agricultural systems and their effects on energy-use patterns, the number of samples (number of farmers) in energy studies is an important issue demanding attention. Many of the papers included in this review mention the exact number of their sample size $[4,6]$, while some have not [7]. According to sampling principles, the sample size should have a logical relation with the number of the statistical population, and would therefore, be in compliance with the standard sampling size determined with the Cochran and Neyman methods (Equations (1) and (2)). This procedure has been used by many authors [5,8-11]. Nevertheless, there are some papers which have not followed this procedure. For example, Alimagham, et al. [12] collected data from 26 soybean farms using a face-to-face questionnaire in Golestan province, but according to the formal statistics for Iran [12], there are 5449 farmers in this area. Based on the Cochran formula at least 358 farms should have 
been investigated. In another paper [13], the sample size of rice producers in the northern provinces of Iran was 50. Due to their small scale, there are more than 400,000 farms in this area [12], and 50 samples are not an adequate representation for the population studied. On the other hand, there is a critical problem in finding enough samples in the target area, as farmers often are not eager to participate in interviews. Nevertheless, researchers are strongly urged to use standard sample sizes for questionnaires as much as possible based on the Cochran and Neyman methods.

In contrast to static surveys, some studies have utilized dynamic surveys and time series data for agricultural energy analyses in Iran. For example, Beheshti Tabar, et al. [14] collected data from 1990 to 2006 years (a 17 years period), audited 19 major irrigated and rain-fed agronomic field crops in Iran and investigated the energy use of inputs and outputs. In another study, Banaeian and Zangeneh [15] studied 8 years (2001-2007) of energy efficiency in corn production of Iran. The data used in these studies were collected from various statistical resources, such as the agricultural statistical yearbook of Iran published by the Agricultural Ministry of the Islamic Republic of Iran, and other data collected from databases available through the Agricultural Ministry of Iran. Using library data in this type of study is relevant and appropriate.

\section{Results}

The results of this review were to collect and discuss the methods used in the analysis of agricultural systems from energy, economic and environmental aspects. Therefore, an important part of the results is dedicated to this part. Creating a horizon for researchers who intend to enter this field of research in the future is possible by studying the methods used and discussing the challenges of these methods presented here. Creating a more comprehensive perspective for researchers to understand the shortcomings of previous studies and move towards the evolution of the process of analysis of agricultural systems in Iran is another result that has been achieved by conducting this study. Also, three important indicators in the pattern of energy consumption for more familiarity of readers with the situation of Iran's agricultural sector are reported here.

\subsection{Synthesis of Results}

\subsubsection{Energy Analysis}

Energy equivalents (energy conversion factors) are numerical values that provide insight into the state of energy of each input. Energy equivalents utilized in the literature are mostly derived from foreign references (i.e., not local and national references related to the target agricultural systems, $[16,17])$, and are used to estimate the energy indicators along with collected sample data. There are some particularly relevant inputs in agricultural systems, but the energy system boundary is not the same in all energy studies. Table 1 shows the most relevant inputs and energy equivalents applied in energy-use pattern studies of agricultural systems.

Table 1. Main inputs and energy equivalents used in agricultural energy systems.

\begin{tabular}{|c|c|c|c|}
\hline \multicolumn{2}{|c|}{ Inputs (Unit) } & Energy Equivalent (MJ Per Unit) & References \\
\hline \multicolumn{2}{|c|}{ Labor (h) } & 1.96 & [18] \\
\hline \multicolumn{2}{|c|}{ Machinery (h) } & 62.7 & [19] \\
\hline \multicolumn{2}{|c|}{ Diesel fuel (L) } & 56.3 & [20] \\
\hline \multirow{4}{*}{ Fertilizers $(\mathrm{kg})$} & Nitrogen & 66.14 & [21] \\
\hline & Phosphate & 12.44 & [21] \\
\hline & Potassium & 11.15 & [3] \\
\hline & Micro & 120 & [3] \\
\hline \multicolumn{2}{|c|}{ Farmyard Manure $(\mathrm{kg})$} & 0.3 & [22] \\
\hline \multirow{4}{*}{ Chemicals $(\mathrm{kg})$} & Herbicide & 356.29 & [23] \\
\hline & Pesticide & 280.44 & [23] \\
\hline & Fungicide & 181.9 & [23] \\
\hline & Insecticide & 101.9 & [8] \\
\hline \multicolumn{2}{|c|}{ Water $\left(\mathrm{m}^{3}\right)$} & 1.02 & [24] \\
\hline \multicolumn{2}{|c|}{ Electricity (kWh) } & 11.93 & [25] \\
\hline
\end{tabular}


In early agricultural energy studies in Iran, four main energy balance indicators were commonly used [18,26-28]. These indicators are well-known from energy studies and almost all the papers reviewed in this survey applied them in their energy balance section (Equations (3)-(6)),

$$
\begin{gathered}
\text { Energy Use Efficiency }=\frac{\text { Energy Output }\left(\mathrm{MJ} \mathrm{ha}^{-1}\right)}{\text { Energy Input }\left(\mathrm{MJ} \mathrm{ha}^{-1}\right)} \\
\text { Energy Productivity }=\frac{\text { Output }\left(\mathrm{kg} \mathrm{ha}^{-1}\right)}{\text { Energy Input }\left(\mathrm{MJ} \mathrm{ha}^{-1}\right)} \\
\text { Specific Energy }=\frac{\text { Energy Input }\left(\mathrm{MJ} \mathrm{ha}^{-1}\right)}{\text { Output }\left(\mathrm{kg} \mathrm{ha}^{-1}\right)} \\
\text { Net Energy = Energy Output }\left(\mathrm{MJ} \mathrm{ha}{ }^{-1}\right)-\text { Energy Input }\left(\mathrm{MJ} \mathrm{ha}^{-1}\right)
\end{gathered}
$$

Other indicators have been introduced and extended in subsequent years. For example, the Energy Intensiveness index applied by Mohammadi and Omid [29] (Equation (7)):

$$
\text { Energy Intensivenss }=\frac{\text { Energy Input }\left(\mathrm{MJ} \mathrm{ha}^{-1}\right)}{\text { Cost of Cultivation }\left(\$ \mathrm{ha}^{-1}\right)} \text {. }
$$

Due to the high consumption of chemical fertilizers, a newer indicator has also been proposed and applied by some authors called the Agrochemical Energy Ratio, which is shown in Equation (8). [30]. A higher ratio of chemical-fertilizer energy consumption may lead to a higher agrochemical footprint [2]. The share of agrochemical energy in low-input agroecosystems and organic farming is usually negligible, while traditional and intensive farming systems are often heavily dependent on agrochemical consumption:

$$
\text { Agrochemical energy Ratio }=\frac{\text { Energy of Agrochemical Inputs }\left(\mathrm{MJ} \mathrm{ha}{ }^{-1}\right)}{\text { Total Input Energy }\left(\mathrm{MJ} \mathrm{ha}^{-1}\right)} .
$$

Some studies [31] have used Equations (9)-(11) for the energy calculations of machinery, electricity for irrigation, and fuel,

$$
M_{E}=E \times \frac{W}{T} \times Q_{h}
$$

where $M_{E}$ is the machinery energy $\left(\mathrm{MJ} \mathrm{ha}^{-1}\right), E$ is a coefficient equal to $62.7 \mathrm{MJ} \mathrm{kg}^{-1}$, which is associated with the energy consumed to produce a machine, $W$ is the weight of the machine, $T$ is the effective lifetime of the machine, and $Q_{h}$ is the total working hours during the production of a crop,

$$
E_{e}=\frac{H \times Q \times E \times T \times L \times G}{3600 \times \varepsilon_{\rho}}
$$

where $E_{e}$ is electricity energy $\left(\mathrm{MJ} \mathrm{ha}{ }^{-1}\right), H$ is the dynamic wellhead, $Q$ is the water flow head $\left(\mathrm{m}^{3} \mathrm{ha}^{-1}\right)$, $E$ is the energy equivalent of electricity $\left(\mathrm{MJ} \mathrm{kWh}^{-1}\right), T$ is the irrigation time (h), $L$ is the number of irrigations per agricultural season, $G$ is the gravitational acceleration $\left(\mathrm{m} \mathrm{s}^{-2}\right)$, and $\varepsilon_{\rho}$ is the pumping efficiency varying between 0.7 and 0.9 ,

$$
F_{C}=F_{h r} \times t
$$

where $F_{C}$ is the fuel consumption required for agricultural operation at $1 \mathrm{ha}\left(\mathrm{L} \mathrm{ha}^{-1}\right), F_{h r}$ is the fuel required for $1 \mathrm{~h}$ operation $\left(\mathrm{L} \mathrm{h}^{-1}\right)$, and $t$ working time of the tractor $\left(\mathrm{h} \mathrm{ha}^{-1}\right)$. 


\subsubsection{Life Cycle Assessment}

Life Cycle Assessment (LCA) methodology has been used for assessing a wide variety of agricultural systems. The first application of LCA in the agricultural systems of Iran began with Pishgar-Komleh, Ghahderijani and Sefeedpari [2] in potato production. LCA studies follow ISO standards [32] which are comprised of four main phases: (1) Definition of goal and scope; (2) Life Cycle Inventory (LCI) analysis, which includes developing a flow diagram of the process being evaluated, developing a data collection plan, data collection and evaluating and reporting the results; (3) impact assessment which includes a selection of impact categories with classification, characterization, normalization and weighting; and (4) interpretation. In an extended methodology, Nikkhah, et al. [33] applied the Analytic Hierarchy Process (AHP) to develop a weighting scheme for the LCA of agricultural production. The system boundary in early energy studies was too limited and was therefore gradually enlarged in later studies. A sample of a flow diagram for watermelon production systems is shown in Figure 2.

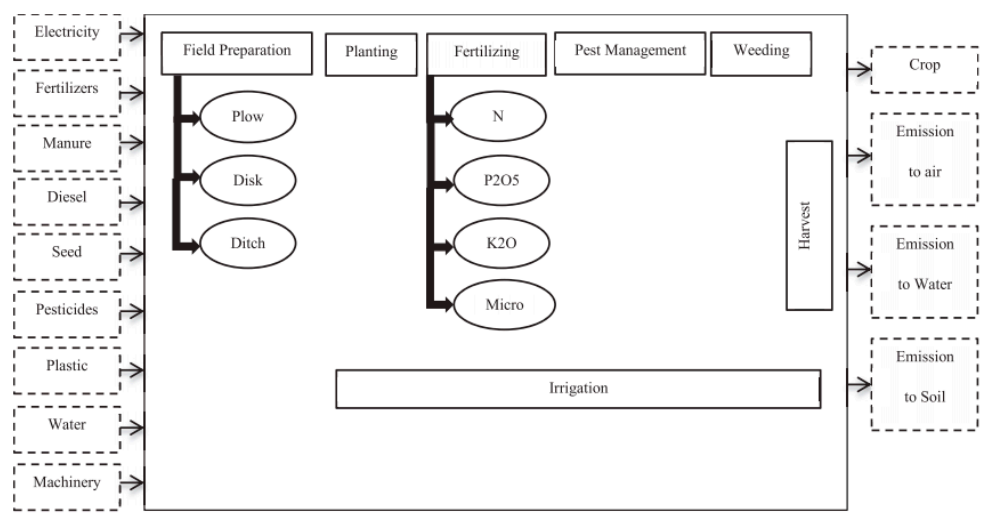

Figure 2. A sample of agricultural system boundary [34].

Environmental impacts include emissions into air, water, and soil. Environmental emissions can be represented by the functional units based on per unit mass (mass base e.g., $\mathrm{kg}$ ) or per unit land (land base e.g., ha). In the literature reviewed here, environmental impact assessments of agricultural systems are tracked in two main manners which depend on the researchers' objectives. Some researchers have used direct emission equivalents (manual calculations of GHG emissions), while others have used software analysis with various methodologies and databases to determine several kinds of emissions.

The total emissions of GHG are determined by Equation (12) [35],

$$
\text { Greenhouse effect }=\sum G W P_{i} \times m_{i}
$$

where $m_{i}$ is the mass of the emission gas $(\mathrm{kg})$ and the score is expressed in terms of $\mathrm{CO}_{2}$ equivalents. Some relevant input inventories and $\mathrm{CO}_{2}$ emission equivalents used in environmental impact assessments of agricultural systems are shown in Table 2.

Table 2. GHG emissions coefficients of agricultural inputs.

\begin{tabular}{cccc}
\hline Inputs (Inventories) & Unit & $\mathbf{C O}_{\mathbf{2}}$ Eq. Unit & References \\
\hline Machinery & $\mathrm{MJ}$ & 0.071 & {$[2]$} \\
Diesel fuel & $\mathrm{L}$ & 2.76 & {$[36]$} \\
Nitrogen & $\mathrm{kg}$ & 1.3 & {$[37]$} \\
Phosphorus & $\mathrm{kg}$ & 0.2 & {$[37]$} \\
Potassium & $\mathrm{kg}$ & 0.2 & {$[37]$} \\
Electricity & $\mathrm{kWh}$ & 0.608 & {$[36]$} \\
Natural Gas & $\mathrm{m}^{3}$ & 0.85 & {$[38]$} \\
FYM & $\mathrm{kg}$ & 0.126 & {$[39]$} \\
Herbicide & $\mathrm{kg}$ & 6.3 & {$[40]$} \\
Insecticide & $\mathrm{kg}$ & 5.1 & {$[39]$} \\
Fungicide & $\mathrm{kg}$ & 3.9 & {$[39]$} \\
\hline
\end{tabular}


There are many software tools to assess environmental impact but most researchers have used various versions of SimaPro software. Life Cycle Inventory Analysis (LCIA) methods involve impact categories that are selected based on the goal and scope definition phase of the study. Characterization factors play a prominent role in LCIA because they convert different inventory inputs into directly comparable impact indicators [34]. The main environmental impact categories and their measurement units in different LCIA methods are summarized in Table 3. Further, "energy use" is a common impact category and many different energy-use indicators are applied in LCA studies; therefore, energy studies can be considered a subset of LCA studies. Finally, Nabavi-Pelesaraei, et al. [41] applied emission coefficients to emission indicators as shown in Table 4.

Table 3. Environmental impact categories and their measurement units.

\begin{tabular}{|c|c|}
\hline Impact Category & Unit \\
\hline Climate change, Global Warming, Greenhouse Gas & $\mathrm{kg} \mathrm{CO} 2$ eq. \\
\hline Ozone Layer Depletion & g CFC-11 eq. \\
\hline Abiotic Depletion & kg Sb eq. \\
\hline Acidification, Terrestrial Acidification & $\mathrm{kg} \mathrm{SO}_{2}$ eq. \\
\hline Eutrophication, Freshwater Eutrophication & $\mathrm{kg} \mathrm{PO}_{4}^{-3}$ \\
\hline Human Toxicity, Freshwater Aquatic Ecotoxicity, Marine Aquatic Ecotoxicity, Terrestrial Ecotoxicity & $\mathrm{kg} \mathrm{1,4-DB} \mathrm{eq.}$ \\
\hline Photochemical Oxidation & $\mathrm{kg} \mathrm{C}_{2} \mathrm{H}_{4}$ eq. \\
\hline Cumulative Energy Demand & MJ eq. \\
\hline
\end{tabular}

Table 4. Emission indices and coefficients for emission equivalents as used in Nabavi-Pelesaraei, Rafiee, Mohtasebi, Hosseinzadeh-Bandbafha and Chau [42].

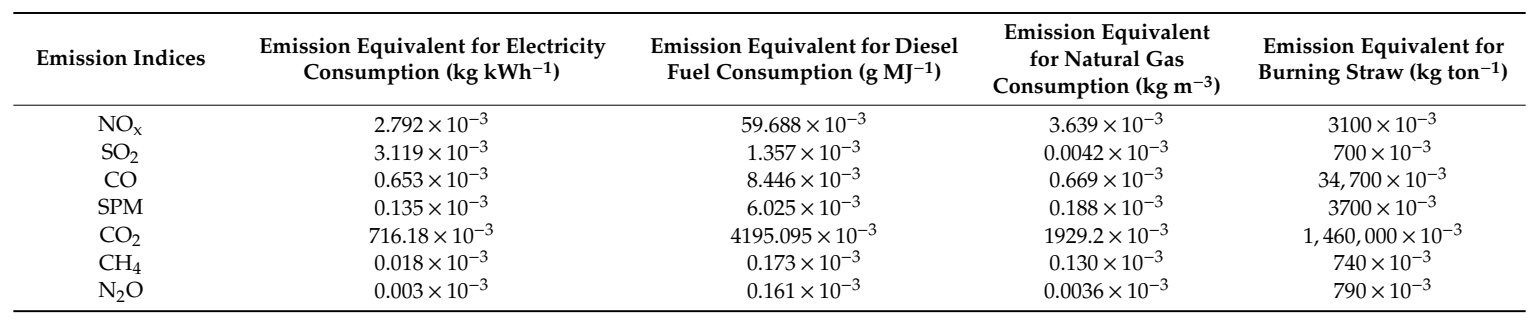

\subsubsection{Economic Indicators}

Some energy studies have included other aspects of agricultural systems, such as economic analysis. The first such studies were those of Mohammadi, Tabatabaeefar, Shahin, Rafiee and Keyhani [19], Shahan, Jafari, Mobli, Rafiee and Karimi [28] and Salami, et al. [43], in which several economic indicators were estimated using the collected sample data. Initially, the following economic indicators were used: Gross Value of Production $\left(\$ \mathrm{ha}^{-1}\right)$, Variable Cost $\left(\$ \mathrm{ha}^{-1}\right)$, Fixed Cost $\left(\$ \mathrm{ha}^{-1}\right)$, Total Cost $\left(\$ \mathrm{ha}^{-1}, \$ \mathrm{~kg}^{-1}\right)$, Gross Return $\left(\$ \mathrm{ha}^{-1}\right)$, Net Return $\left(\$ \mathrm{ha}^{-1}\right)$, and Benefit to Cost Ratio [18]. Later, Total Production Value $\left(\$ \mathrm{ha}^{-1}\right)$ and Productivity $\left(\mathrm{kg} \$^{-1}\right)$ were used by Zangeneh, Omid and Akram [5]. The formulas for these indicators are shown in Equations (13)-(17):

$$
\begin{gathered}
\text { Total Production Value }=\text { Crop Yield }\left(\mathrm{kg} \mathrm{ha}^{-1}\right) * \text { Crop Price }\left(\$ \mathrm{~kg}^{-1}\right) \\
\text { Gross Return }=\text { Total Production Value }\left(\$ \mathrm{ha}^{-1}\right)-\text { Variable Cost }\left(\$ \mathrm{ha}^{-1}\right) \\
\text { Net Return }=\text { Total Production Value }\left(\$ \mathrm{ha}^{-1}\right)-\text { Total Production } \operatorname{Cost}\left(\$ \mathrm{ha}^{-1}\right) \\
\text { Benefit to Cost Ratio }=\frac{\text { Total Production Value }\left(\$ \mathrm{ha}^{-1}\right)}{\text { Total Production } \operatorname{Cost}\left(\$ \mathrm{ha}^{-1}\right)} \\
\text { Productivity }=\frac{\text { Crop Yield }\left(\mathrm{kg} \mathrm{ha}^{-1}\right)}{\text { Total Production } \operatorname{Cost}\left(\$ \mathrm{ha}^{-1}\right)}
\end{gathered}
$$


Last, in order to address the sustainability of agricultural systems more broadly and thoroughly. According to Stoellinger, et al. [42] pending either legislative action or formal agency guidance, utilization of the social cost of carbon in analyses of energy development projects on federal land under the National Environmental Policy Act is not required. However, research trends indicate that in the future there will increasingly necessary to apply quantitative analysis for determination of proposed energy projects impacts on climate change. Social cost analysis is a quantitative analysis which accurately assess the appropriateness and accuracy of impact associated with greenhouse gas. The social cost of carbon is an estimate for economic amount of the extra impact caused by the emission or reduction of an additional ton of carbon (in the form of carbon dioxide) at any point in time [38], social costs for emission indicators have begun to be investigated and are shown in Table 5 [41].

Table 5. Social cost coefficients for emission indices.

\begin{tabular}{ccccccccc}
\hline Social Cost for Emission Indices $\left(\$ \mathrm{~kg}^{-1}\right)$ & $\mathrm{CO}_{2}$ & $\mathrm{~N}_{2} \mathrm{O}$ & $\mathrm{CH}$ & $\mathrm{PM} 10$ & $\mathrm{NO}_{\mathrm{x}}$ & $\mathrm{SO}_{2}$ & $\mathrm{CO}$ & $\mathrm{NH}_{3}$ \\
\hline Amount & 0.01 & 4.58 & 0.21 & 4.3 & 0.6 & 1.825 & 0.187 & 2.83 \\
\hline
\end{tabular}

\subsubsection{Cobb-Douglas Production Function}

A production function investigates the relation of inputs and outputs in agricultural systems. Generally, researchers have tested different relation functions and selected the Cobb-Douglass production function as appropriate based on statistical significance and expected signs of parameters [43]. The Cobb-Douglas production function is expressed by Equation (18) [44],

$$
\ln Y_{i}=a+\sum_{j=1}^{n} \alpha_{j} \ln \left(X_{i j}\right)+e_{i}, \quad i=1,2, \ldots, n
$$

where $Y_{i}$ denotes the yield of the $i$ th farm, $X_{i j}$ the vector of $j$ th input used in $i$ th farm in the production process, $a$ is the constant term, $\alpha_{j}$ represents coefficients of inputs which are estimated from the model, and $e_{i}$ is the error term of $i$ th farm.

\subsubsection{Marginal Physical Productivity}

In a mathematical model of energy in agricultural systems the sensitivity analysis shows how uncertainty in inputs (energy) can change the output (yield). The Marginal Physical Productivity (MPP) method is a suitable index that determines the response coefficient of the inputs. The MPP (Equation (19)) of the various inputs is calculated using the $\alpha_{j}$ of the various energy inputs [45],

$$
M P P_{x j}=\frac{G M(Y)}{G M\left(X_{j}\right)} \times \alpha_{j}
$$

where $M P P_{x j}$ is marginal physical productivity of $j$ th input, $\alpha_{j}$ is the regression coefficient of $j$ th input, $G M(Y)$ is the geometric mean of yield and $G M\left(X_{j}\right)$ is the geometric mean of $j$ th input energy on per hectare basis. This model shows how much yield changes with a one-unit increase in each energy input while other production variables are fixed [46].

\subsubsection{Data Envelopment Analysis}

Data Envelopment Analysis (DEA) is a nonparametric linear programming-based technique, i.e., it does not require specification of the functional form of the production function [25,47]. This method can be used to compute the relative efficiency of a number of Decision Making Units (DMUs) on the basis of multiple inputs and outputs [47]. Efficiency calculations can be input-oriented (minimize inputs with existing outputs) and output-oriented (maximize outputs with existing inputs) (Equation (20)). The input-oriented model is becoming more common among researchers because 
farmers can only manage the inputs to increase the relative efficiency in farms and are unable to directly change the output [48].

In fact, input-oriented efficiency in agricultural systems is the ability of a DMU to attain the same amount of output (yield) while minimizing inputs (energy consumption) (Equation (20)),

$$
\text { Ef ficiency }=\frac{\text { Weighted sum of outputs }}{\text { Weighted sum of inputs }}
$$

Mathematically, efficiency can be stated as Equation (21):

$$
\text { Efficiency }=\frac{u_{1} y_{1}^{j *}+u_{2} y_{2}^{j *}+\ldots+u_{N} y_{N}^{j *}}{v_{1} x_{1}^{j *}+v_{2} x_{2}^{j *}+\ldots+v_{M} x_{M}^{j *}}
$$

where, $u_{1} \ldots u_{N}$ are the weights given to output $n(n=1 \ldots N) ; y_{1}^{j *} \ldots y_{N}^{j *}$ are the amounts of output $n(n=1 \ldots N)$ of DMU $j^{*} ; v_{1} \ldots v_{M}$ are the weights given to input $m(m=1 \ldots M) ; x_{1}^{j *} \ldots x_{M}^{j *}$ are the amounts of input $m(m=1 \ldots M)$ to DMU $j^{*}$; and $j^{*}$ is the DMU under consideration [47]. The efficiency value is always a number between 0 and 1 .

The initial optimization model was Constant Returns to Scale (CRS) introduced by Charnes, et al. [49] for computation of Technical Efficiency (TE). Six years later, Banker, et al. [50] developed Variant Returns to Scale (VRS) for Pure Technical Efficiency (PTE). According to Banker et al. (1984), overall efficiency segregated into TE and Scale Efficiency (SE) (Equation (22)) as follows:

$$
\text { Scale Efficiency }=\frac{\text { Technical Efficiency }}{\text { Pure Technical Ef ficiency }}=\frac{C R S \text { score }}{V R S \text { score }} .
$$

This unique decomposition shows the reason for inefficiency: either from inefficient operation (PTE) or from disadvantageous conditions (SE).

Researchers have applied the DEA technique to divide their DMUs into efficient and inefficient producers and then provide the target inputs to attain the same amount of outputs for inefficient producers. Target energy inputs are introduced as an appropriate guideline to identify the source of excessive energy consumption. Researchers have used these results to save energy from different input sources [47] and make recommendations to farmers. In the analysis of DMUs' efficiency by DEA, another index is sometimes imported by researchers: The Energy Saving Target Ratio (ESTR) index [1]. This ratio shows the amount of energy-saving potential for each inefficient DMU if it operates as an efficient DMU (i.e., lower level of inefficiency). The ESTR value can vary from 0 to 1 in which a value of 0 shows that a DMU is efficient and located on the frontier [51] (Equation (23)). In this equation $j$ represents $j$ th DMU [52]:

$$
\operatorname{ESTR}_{j}=\frac{(\text { Energy Saving Target })_{j}}{(\text { Actual Energy Input })_{j}} .
$$

\subsubsection{Artificial Neural Networks (ANN)}

An ANN structure consists of a layer of input neurons, a layer of output neurons, and one or more hidden layers. The output, which is completely dependent on the specific transfer function, is sent to the next layer of neurons by weighted connections. Then, the neuron outputs will be completed by computing the sum of weighted inputs that depend on their transfer function for output. A schematic diagram of a typical multilayer feed-forward neural network architecture used for basil yield prediction is shown in Figure 3 [53]. 


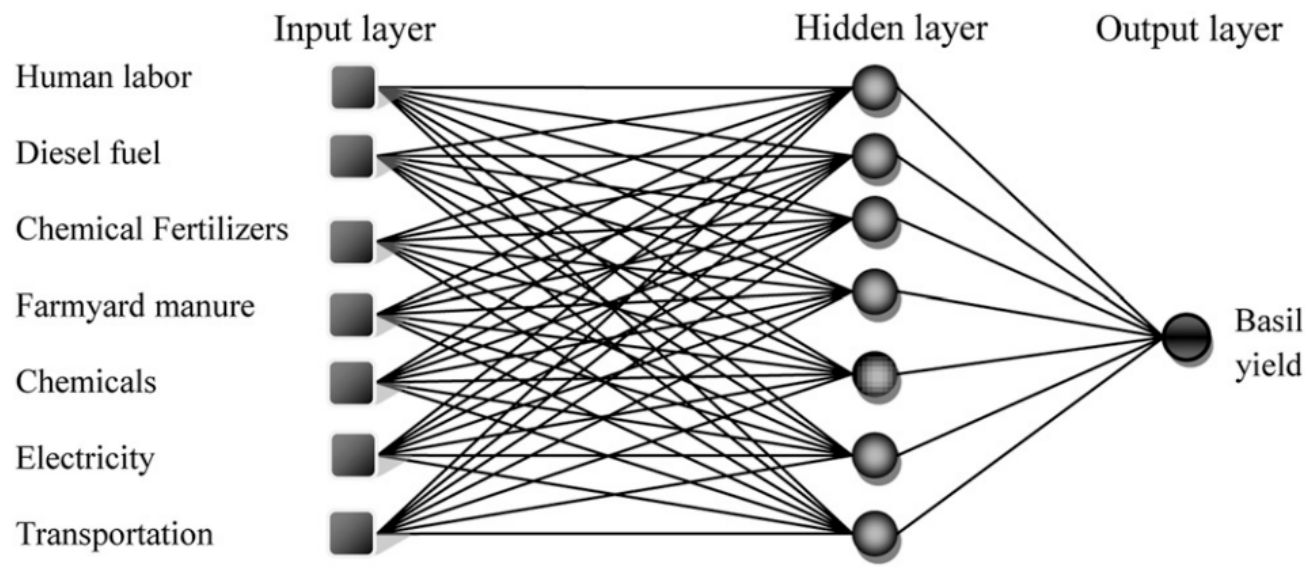

Figure 3. Topology of a fully connected three-layered multilayer perceptron network [53].

In the papers reviewed, the optimum architecture has been awarded to the topology with the lowest Root Mean Square Error (RMSE) and Mean Absolute Error (MAE) and the highest coefficient of determination $\left(R^{2}\right)$. These selection criteria for the best ANN topologies are widely used in the literature and defined as follows in Equations (24)-(26) [6,54],

$$
\begin{gathered}
\text { RMSE }=\sqrt{\frac{1}{n} \sum_{i=1}^{n}\left(Y_{\text {predicted }}-Y_{\text {actual }}\right)^{2}} \\
R^{2}=\frac{\sum_{i=1}^{n}\left(Y_{\text {predicted }}-Y_{\text {actual }}\right)^{2}}{\sum_{i=1}^{n}\left(Y_{\text {predicted }}-Y_{\text {mean }}\right)^{2}} \\
\text { MAE }=\frac{1}{n} \sum_{i=1}^{n}\left|Y_{\text {actual }}-Y_{\text {predicted }}\right|
\end{gathered}
$$

where $Y_{\text {actual }}$ is the actual amount of yield and $Y_{\text {predicted }}$ is the value measured and predicted by the developed model and $n$ is the number of forecasts.

\subsubsection{Adaptive Neuro-Fuzzy Inference System (ANFIS)}

Researchers have used ANFIS widely in energy systems because like ANN it can also predict outputs using inputs. It is actually a combination of ANNs and fuzzy-logic models which gives it the ability of modeling uncertain and imprecise data. Consisting of if-else rules and input-output couples of fuzzy data, ANFIS uses the neural network's learning algorithms for training. Evaluation of ANFIS model accuracy is similar to that of ANN models, i.e., the best model generates the highest correlation coefficient and lowest RMSE and MAE (Equations (24)-(26)).

\subsection{Energy Status in Farm Crops}

All papers from 2008 to 2019 are reviewed and energy indices in different crops compared in Figures 4 and 5. For example, there are eight papers in watermelon energy consumption in the literature, so reported indicators are the average amount of them [34,55-61]. The results revealed that tomato is the most energy consumer between the agricultural crops of Iran and sugarcane, cucumber and alfalfa are in the following places. On the other hand, the sunflower is the least energy consumer between the farm crops of Iran. The average of Total Energy Input (TEI) in farm crops of Iran in the studied period is $48,029 \mathrm{MJ} \mathrm{ha}^{-1}$. 


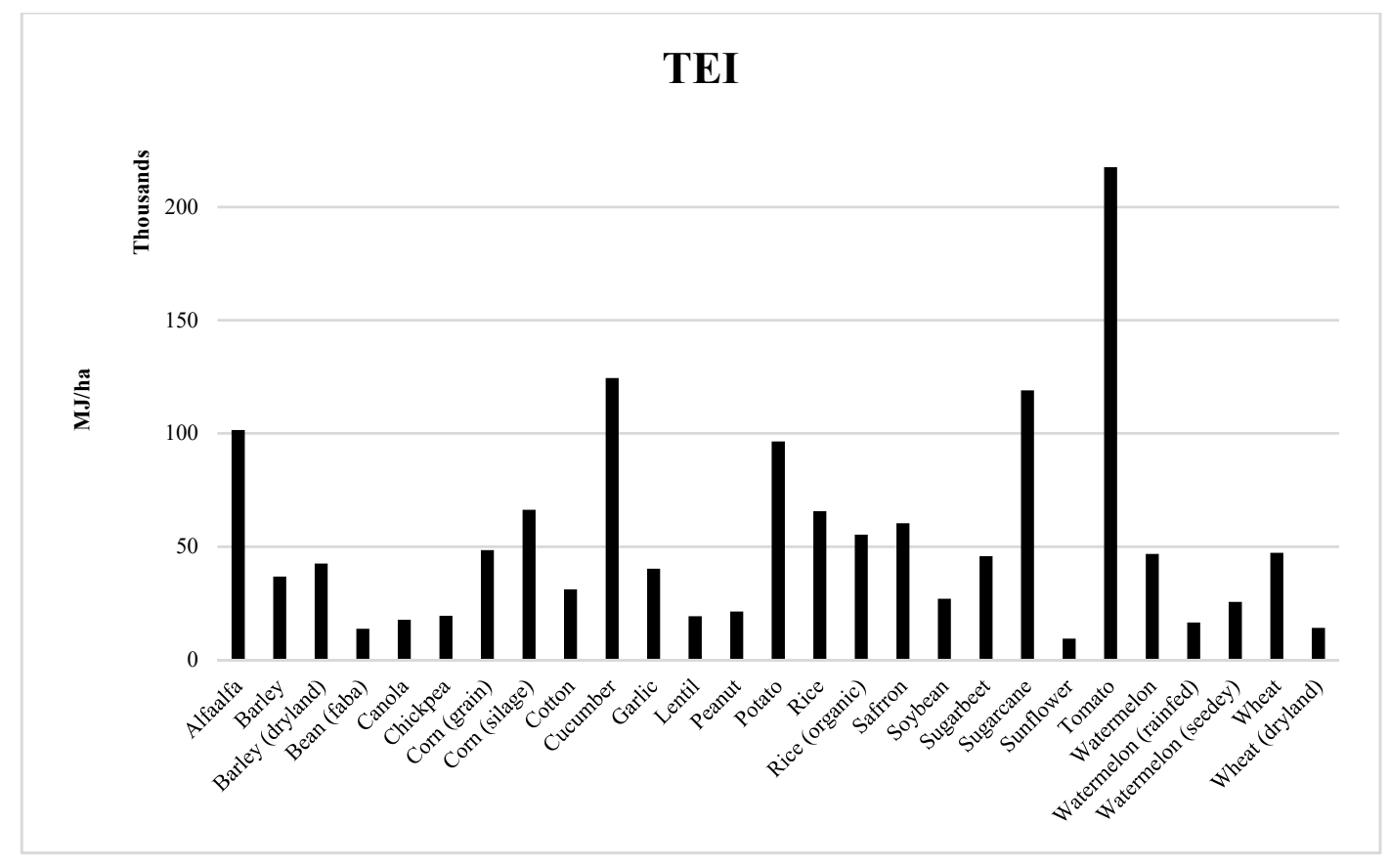

Figure 4. TEI of farm crops.

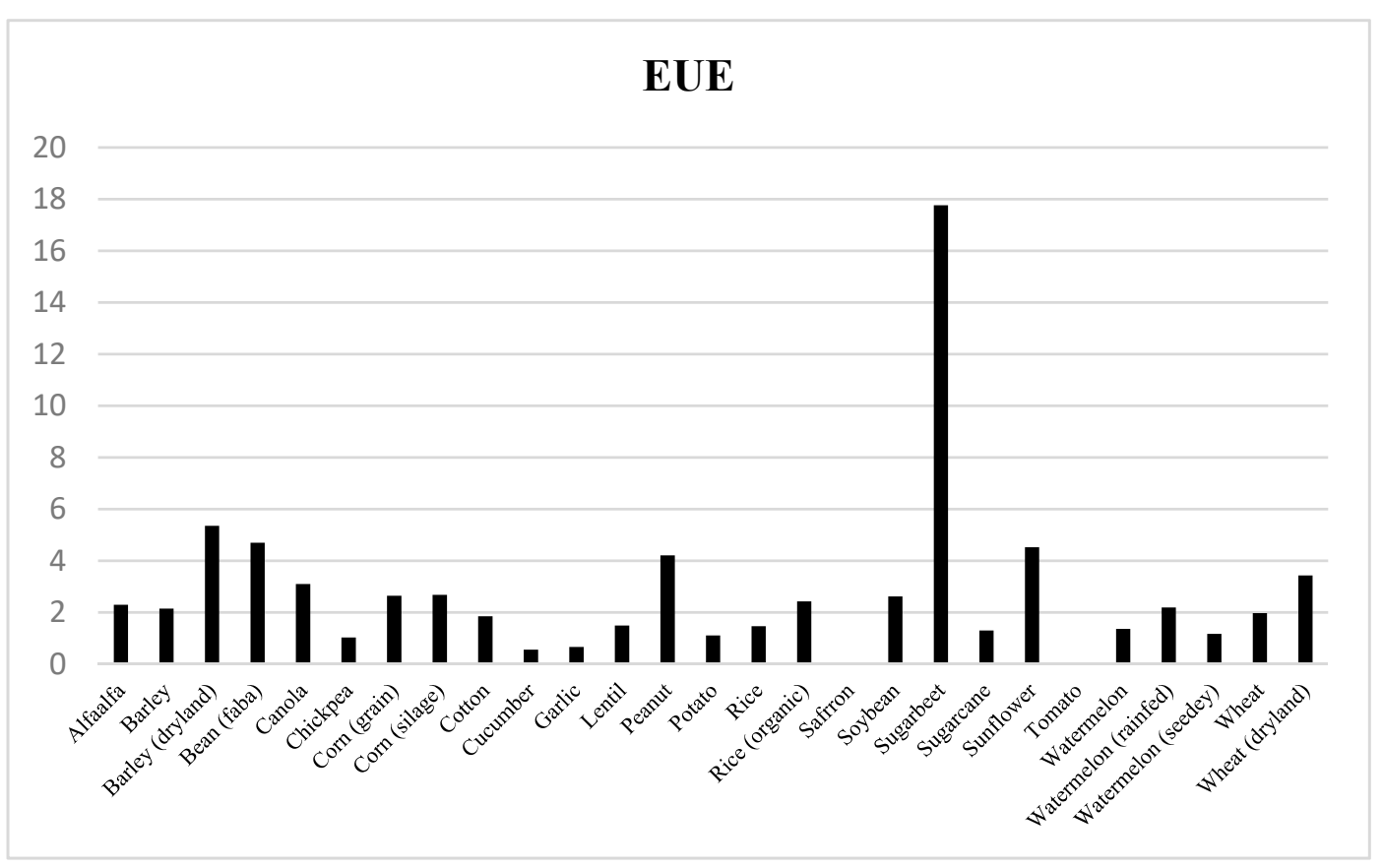

Figure 5. Energy Use Efficiency (EUE) of farm crops.

According to the results, sugar beet has the most Energy Use Efficiency (EUE). This is due to its output energy equivalent by $16.80 \mathrm{MJ} \mathrm{kg}^{-1}$ [62]. The least EUE belongs to saffron, due to traditional saffron production method in Iran, most of the operations except land preparation and fertilizer spraying are implemented by human labor [63]. The produced saffron is about $3.7 \mathrm{~kg} \mathrm{ha}^{-1}$ in the best condition. Although the cultivation of saffron is not efficient from the viewpoint of energy balance while it is significantly economic. Khanali, Movahedi, Yousefi, Jahangiri and Khoshnevisan [63] stated that in order to create a better balance between the energy of inputs and saffron yield, we should try to increase saffron yield and subsequently its energy productivity. 
Results of net energy showed that sugar beet, due to high energy equivalent has the highest energy value among farm crops. There are some crops that have negative net energy, i.e., cucumber, garlic, saffron, and tomato.

\section{Discussion}

\subsection{Summary of Evidence}

The papers representing the first generation of farm-crop energy studies in Iran, published in 2008, were focused on Ardabil province. Mohammadi, Tabatabaeefar, Shahin, Rafiee and Keyhani [19] studied energy consumption in potato production and Shahin, Jafari, Mobli and Karimi [26] and Shahan, Jafari, Mobli, Rafiee and Karimi [27] studied energy indicators in wheat production. From 2008 to 2019, there have been 131 papers from Iranian researchers in different provinces of Iran according to SCOPUS and Google Scholar. Energy studies have been performed in $80 \%$ of Iran's provinces (Figure 6). Most papers are from Golestan and Isfahan provinces, which account for $32 \%$ of published studies. The temporal trend of published energy analyses in Iran is shown in Figure 7.

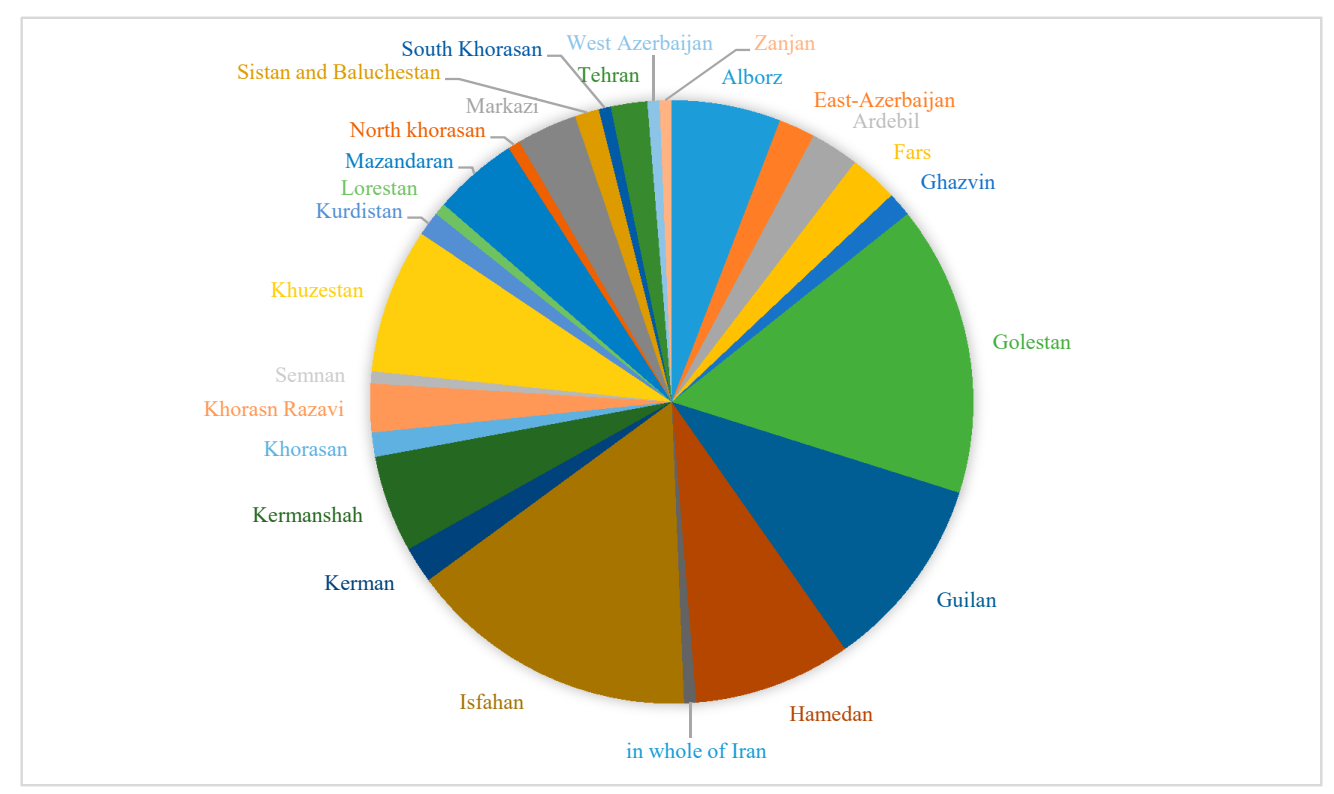

Figure 6. Frequencies of published papers according to the provinces of Iran.

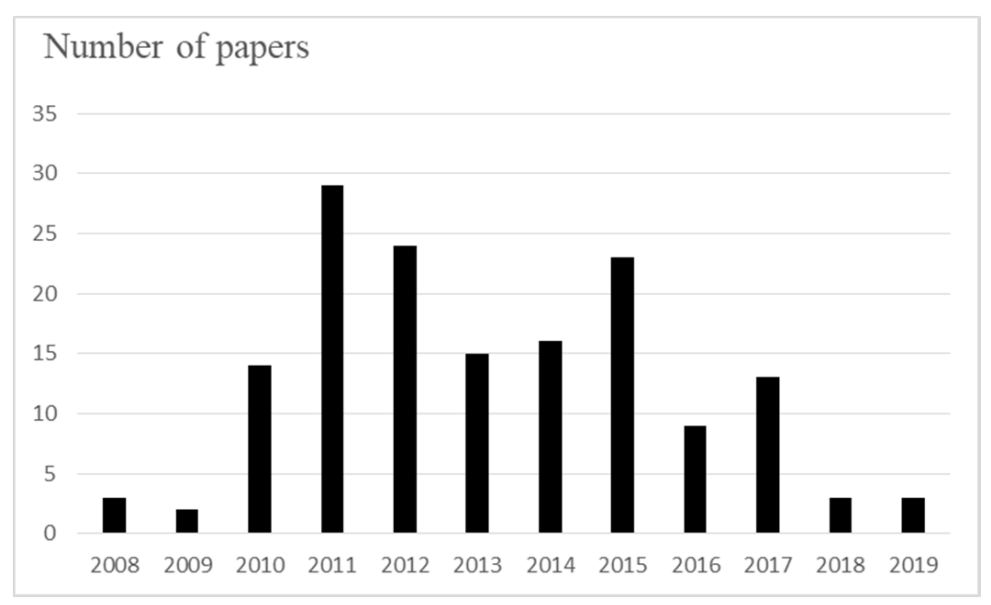

Figure 7. Number of energy analyses of Iranian farm crops published annually. 
The most typical design in these kinds of studies is an investigation of one crop per paper, though there are a few papers which study more than one crop [14,64-66]. The most common crop type and focus among these research papers pertain to wheat energy analysis. Rice and corn take second, and third place, respectively. Figure 8 shows the distribution of papers according to crop type.

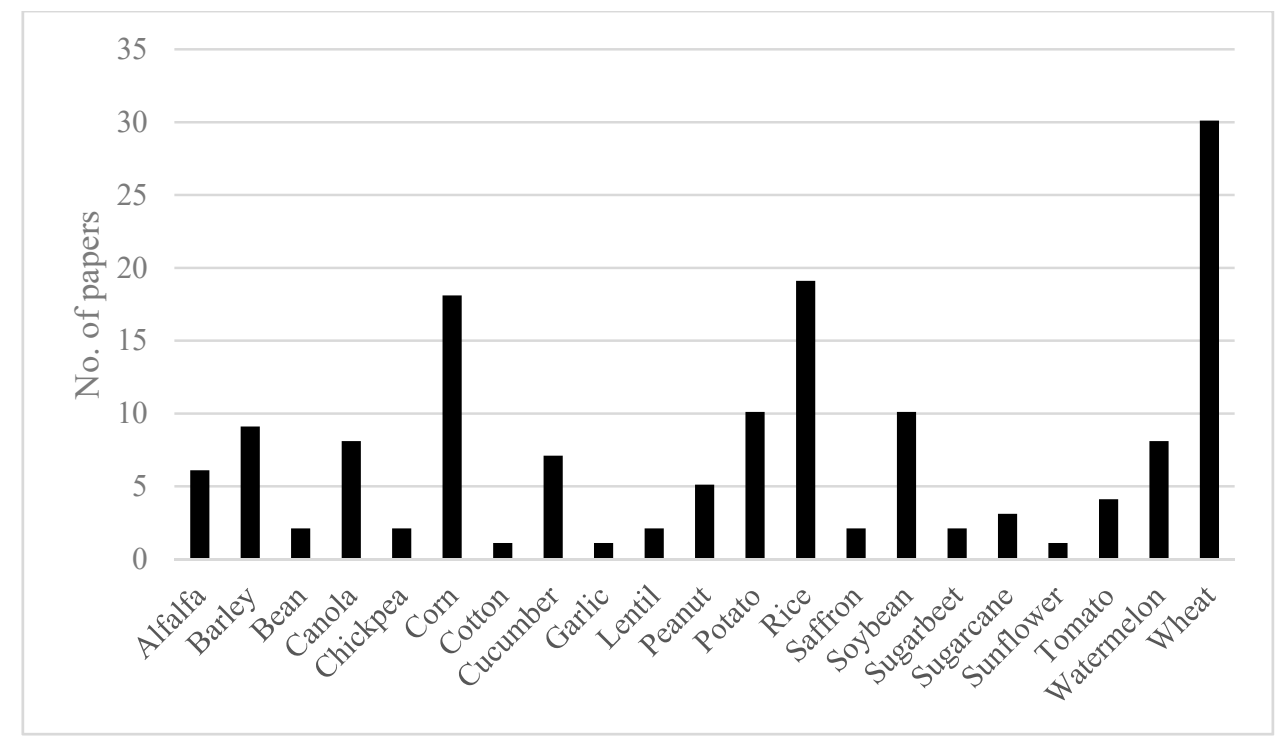

Figure 8. Number of Iranian energy analyses published per crop.

Artificial Intelligence Potential in Future Research

Some researchers have combined different analytical and operational research methods with LCA to perform more comprehensive analyses, including new aspects of systems analysis in agricultural systems. For example, Zangeneh, et al. [67] applied ANNs to predict the machinery energy ratio in potato production systems of Iran. In energy studies, ANNs mostly have been applied to estimate the yield or output energy of crop production, like corn silage [68], basil [53], wheat [69], and grain corn [70]. Some authors have tried to use ANNs to predict the environmental indicators of farm crop production like wheat [37,71], potato [72], lentil [73], apple [74], and kiwi [75]. A sensitivity analysis can be carried out at the end of the ANN methodology. For example, Khoshnevisan, Rafiee, Omid and Mousazadeh [36] showed that seed, fertilizer, and chemical pesticides had the highest and machinery had the lowest sensitivity in relation to output energy, which was $52 \%$, and $5 \%$, respectively. In other research, Elhami, Khanali and Akram [73] determined the most important inputs affecting yield and environmental impacts in lentil production to be farmyard manure and machinery, respectively. ANNs in energy flow modeling have been compared with mathematical models. Recently, Taheri-Rad, Khojastehpour, Rohani, Khoramdel and Nikkhah [6] showed that the ANN model was more accurate than the Cobb-Douglas model in estimating of paddy rice cultivar yields.

Fuzzy set theory has been used to analyze some agricultural systems to study energy, economic, and environmental issues. For example, Khoshnevisan, et al. [76] applied a c-means fuzzy clustering model to identify efficient and inefficient wheat farms. The division of the farms was based on three features: input/output energy ratio, greenhouse gas ratio, and benefit to cost ratio. ANFIS (a combination of fuzzy set theory with ANNs) can be used to predict output energy using input energies $[77,78]$. ANFIS was first used by Naderloo, Alimardani, Omid, Sarmadian, Javadikia, Torabi and Alimardani [54] to predict the yield of irrigated wheat in Ghazvin province in Iran. Khoshnevisan, et al. [79] predicted tomato production in the Isfahan province of Iran by finding the best ANFIS topology. A similar analysis has been performed by other researchers to estimate potato and wheat yields by ANFIS using energy inputs [78,80]. ANFIS has been used for modeling other aspects of agricultural systems as well. Mousavi-Avval, Rafiee, Sharifi, Hosseinpour and Shah [65], for example, 
implemented an intelligent system of three-level ANFIS to predict energy, economic, and environmental indicators based on different inputs [65]. Khoshnevisan, Rafiee, Iqbal, Shamshirband, Omid, Anuar and Abdul Wahab [79] applied both ANNs and ANFIS based models in the prediction of tomato production. They showed that the ANFIS-based model had lower RMSE and Mean Absolute Percentage Error (MAPE) and a higher correlation coefficient (R). Therefore, ANFIS models showed better performance for energy consumption modeling in tomato production, meaning that the use of fuzzy rules in ANFIS is more effective than ANNs.

Recently, multi-objective optimization has been applied to maximize the output yield, energy, and benefit-to-cost ratio or to minimize input energy and environmental impacts $[56,66]$. As in previous studies, the prediction tools (ANNs and ANFIS) were compared with each other and, in some studies, to different optimization tools. For example, both DEA and MOGA (Multi-Objective Genetic Algorithm) were applied to estimate the optimum energy requirement for wheat production [81]. The results showed that the total optimum energy requirement of MOGA was significantly less than that of DEA. Also, Khoshnevisan, Bolandnazar, Shamshirband, Shariati, Anuar and Mat Kiah [34] and Elhami, et al. [82] applied MOGA and DEA simultaneously to minimize environmental impacts and maximize crop yield. Nabavi-Pelesaraei, et al. [83] analyzed the flow of energy, CExD, and environmental emissions in paddy rice farms. Then, the potential of each input to reduce total energy consumption was determined by DEA and MOGA and the best patterns introduced into the paddy field production. Nabavi-Pelesaraei, Rafiee, Mohtasebi, Hosseinzadeh-Bandbafha and Chau [42] introduced MOGA as an appropriate optimization method in locating the best combination of inputs, and applied this method to minimizing energy consumption and environmental impacts, as well as maximizing the benefit-to-cost ratio.

The main aim of such combinations is for making predictions and merging different aspects of energy, economic and environmental indicators simultaneously in an effort to achieve the best agricultural systems. In other words, researchers are trying to find the most sustainable agricultural systems. However, it is apparent that the social dimension is usually missing from these studies. At the same time, new indicators pertaining to sustainability are being introduced by researchers to analyze different aspects of agricultural systems. For example, Yousefi, Damghani and Khoramivafa [30] has used the following formula to investigate sustainability,

$$
I_{S}=\left[C_{O}-C_{I}\right] /\left[C_{I}\right]
$$

where $I_{S}$ the index of sustainability is, $C_{O}$ is the sum of all outputs expressed in carbon equivalents, $C_{I}$ is the sum of all inputs expressed in carbon equivalent which represented the carbon content embodied in all inputs.

\subsection{Limitations}

\subsubsection{Coordination of Research with Iranian Agriculture Sector}

It is reasonable to expect that research priorities in crop energy studies would correspond to the importance of crops nationally. Figure 9 presents the average share (from 1978-2013) of each crop's cultivated area in Iran for comparison. Wheat is the most cultivated crop in Iran [84], and indeed we find that wheat has also been the most frequently studied of all crops (Figure 6). Barley is the second most important crop in terms of cultivated area, but has not been studied proportionately in the literature. Energy studies should help farmers and government officials better understand and develop ways to optimize energy use patterns. Therefore, these studies should proceed according to the priorities of policies, crops, and regions to improve energy efficiencies. We would urge researchers to consider these patterns in making choices of crop types and regions in future research to address needs, while also avoiding repetitive research. For example, there are similar input-output energy studies in the journal Energy in successive years (2010 and 2011) in Hamedan province [5,85]. This duplication occurred as the later paper [85] did not refer to the first paper [5]. 


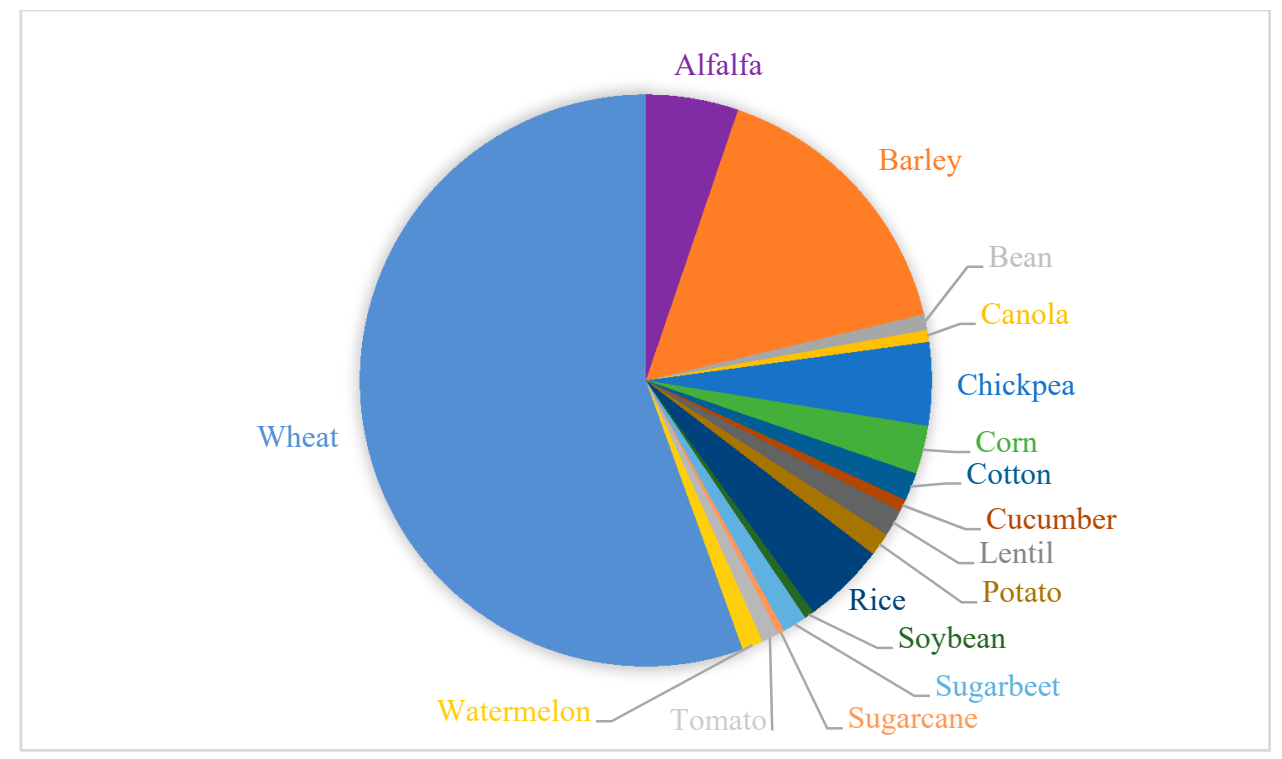

Figure 9. Share of cultivated area per crop based on the average from 1978-2013 in Iran [84].

The correlation between the number of energy studies and the production volume of farm crops can also guide future research priorities of Iranian researchers. Wheat, corn, alfalfa, and sugar beet rank as the top four crops based on production volume in Iran [84]. According to Figure 10, the $\mathrm{R}^{2}$ (coefficient of determination) of the number of published papers and the production amount of farm crops is just 0.47 . This suggests more attention is needed to better align research efforts with the actual conditions of Iran's agricultural sector. Of course, it is also important that the technology level of agricultural production systems is considered by researchers when selecting crops for their studies.

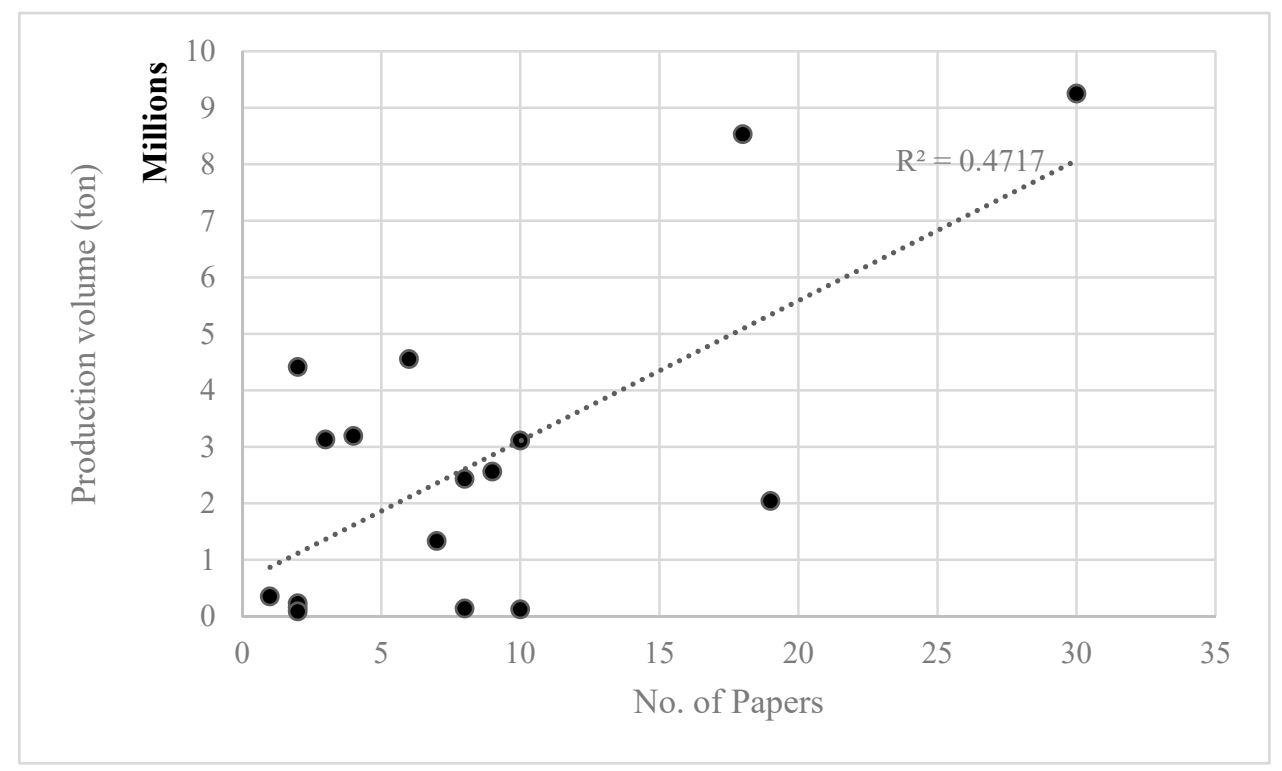

Figure 10. Correlation between production volume and published energy studies for farm crops of Iran (2008-2019).

\subsubsection{Local Energy Equivalents}

Most of the papers used the conversion factors proposed by other authors outside of Iran, while the energy used to produce each input in Iran may differ from other countries in terms of the sources or values. Although, the energy conversion factor for food, not agricultural products, can be developed 
and used at a wide range of geographic scales, from local to regional to national levels [86]. However, the calculation of energy indicators by local energy equivalents would be more precise. There is a critical need to estimate local energy equivalents for inputs in each country and also for Iran.

\subsubsection{Sample Size}

Another very important issue that must be considered by researchers is the number of samples required to estimate energy indices. In some cases, it has been observed that the number of samples is not well observed, which can damage the validity of the results. Therefore, it is emphasized that future researchers must pay serious attention to the number of samples they evaluate.

\subsection{Conclusions}

We have reviewed the published literature on farm crop energy analysis in Iran from 2008 to 2019. Although, there have been many papers pertaining to this topic published in Iran, there has not yet been a systematic review that comprehensively collects all of the applied methodology and provides a foundation and direction for future research. Here we have provided step-by-step guidelines for future researchers in this area by addressing the following questions: (1) What methodologies are regularly applied in such analyses? (2) Which crops and regions are the most studied by researchers? It is obvious that energy production and consumption are costly and lead to negative environmental impacts, so researchers have focused on the environmental consequences of energy use along with the economic consequences. Gradually, complementary analyses have evolved and the resulting work, with the help of artificial intelligence, has been more complete. We have offered readers advice and guidance for future work based on the considerable amount of progress that has already been made. Complementary analyses to predict and optimize output indicators or determine the importance and sensitivity of inputs have also been shared. A conceptual diagram based on the research objectives, methodologies, and results of the reviewed papers is shown in Figure 11.

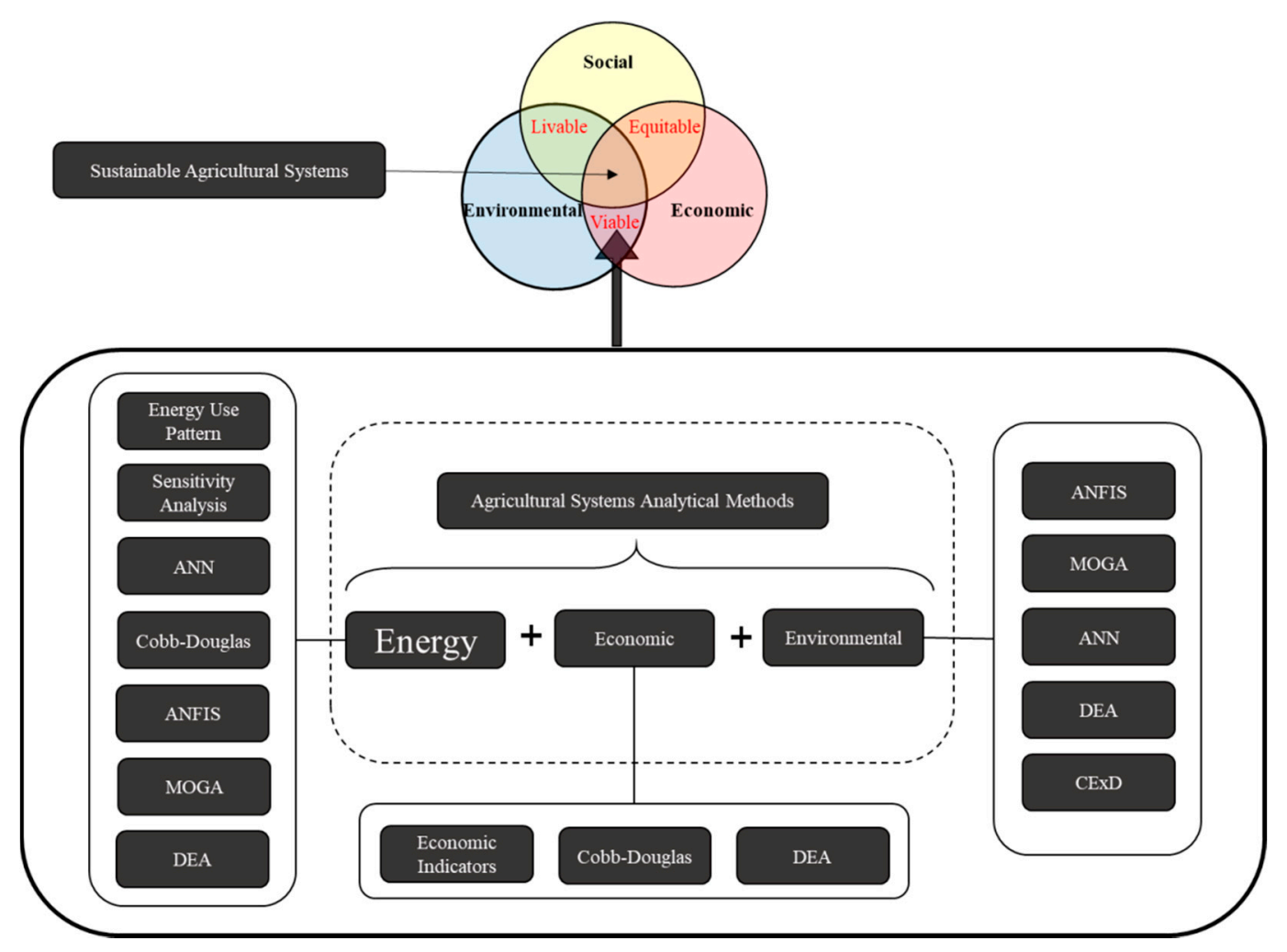

Figure 11. Conceptual diagram of agricultural systems analyses in Iran. 
There is still a critical need to make recommendations to farms that will allow them to optimize their energy-use patterns. A few papers have provided general recommendations for farmers to reduce their energy use, but these kinds of proposals are often not practical for farmers or relevant to the specific agricultural system boundaries. In this regard, optimization methods can make useful contributions and partially fill this gap. DEA- and MOGA-assisted research can result in practical recommendations to decrease the use of inefficient energy inputs in order to improve the overall energy balance in agricultural systems.

Achieving sustainable agricultural systems is the ultimate aim of all such research endeavors. In sustainable agricultural systems, researchers mainly focus on natural resource management but must also consider interrelationships with social and economic systems. Therefore, a multi-objective optimization problem is needed. In the papers reviewed here, social aspects are often neglected but results show that efforts can help lead to viable agricultural systems (Figure 9).

Although environmental regulators and National Environmental Policy Act do not require social costs of environmental emissions in analysis of energy development projects, but research trends show that quantitative metrics in social aspects may be needed in the future to achieve more accurate results. With this in mind, future research should consider social factors and also quantitative metrics to move systems to the ultimate goal of sustainability, as Nabavi-Pelesaraei, Rafiee, Mohtasebi, Hosseinzadeh-Bandbafha and Chau [41] did in considering the social costs of emissions in rice postharvest factories.

Finally, this review revealed that there are some points which future studies in agricultural systems analysis should pay extra attention to: (a) Applying a suitable sampling method and number of samples in the selected region, (b) it is recommended to measure the consumption of important inputs that have a large impact on energy consumption pattern in the farms. The method of data collection in the reviewed articles in all reviewed papers was the use of questionnaires and interviews with farmers. Since a significant population of farmers in developing countries, including Iran, are considered smallholders, so they do not have a clear and codified accounting system. Therefore, interviewing such farmers to estimate the consumption of each of the inputs in the crop production cycle is risky. The main foundation of energy studies is data on inputs and crop yield. Therefore, it is essential that researchers pay close attention to ensure the accuracy of this data. It is worthwhile to conduct field data sampling by the researcher in several cases, at least to verify the data collected through interviews; (b) implementing compatible equivalent factors and methods in inventory analysis, (c) including social aspects as well as energy, environmental, and economic aspects, (d) applying multi-objective optimization toward designing sustainable systems, and (e) transforming results into precise recommendations to assist farmers.

Author Contributions: The idea for writing this review article was first proposed by M.Z. The general structure and sections to be addressed were determined by him. N.B. conducted the literature review to find the articles, categorize them, extract the data, and summarize the results reported in them. S.C. participated in writing stages of the manuscript. All authors have read and agreed to the published version of the manuscript.

Funding: This research received no external funding.

Conflicts of Interest: The authors declare no conflict of interest.

\section{Abbreviations}

$\begin{array}{ll}\text { AI } & \text { Artificial Intelligence } \\ \text { ANFIS } & \text { Adaptive Neuro-Fuzzy Inference System } \\ \text { ANN } & \text { Artificial Neural Networks } \\ \text { ANOVA } & \text { Analysis of Variance } \\ \text { CExD } & \text { Cumulative Exergy Demand Analysis } \\ \text { DE } & \text { Direct Energy } \\ \text { DEA } & \text { Data Envelopment Analysis } \\ \text { EP } & \text { Energy Productivity } \\ \text { EUE } & \text { Energy Use Efficiency }\end{array}$




$\begin{array}{ll}\text { FYM } & \text { Farm Yard Manure } \\ \text { GHG } & \text { Greenhouse Gas } \\ \text { GWP } & \text { Global Warming Potential } \\ \text { IDE } & \text { In-Direct Energy } \\ \text { IE } & \text { Input Energy } \\ \text { LCA } & \text { Life Cycle Analysis } \\ \text { LCI } & \text { Life Cycle Inventory } \\ \text { LCIA } & \text { Life Cycle Inventory Analysis } \\ \text { MOGA } & \text { Multi-Objective Genetic Algorithm } \\ \text { MPP } & \text { Marginal Physical Productivity } \\ \text { NRE } & \text { Non-Renewable Energy } \\ \text { PTE } & \text { Pure Technical Efficiency } \\ \text { RE } & \text { Renewable Energy } \\ \text { SE } & \text { Scale Efficiency } \\ \text { TE } & \text { Technical Efficiency } \\ \text { TEI } & \text { Total Input Energy } \\ \text { TES } & \text { Total Energy Saving }\end{array}$

\section{References}

1. Hosseinzadeh-Bandbafha, H.; Nabavi-Pelesaraei, A.; Khanali, M.; Ghahderijani, M.; Chau, K.-W. Application of data envelopment analysis approach for optimization of energy use and reduction of greenhouse gas emission in peanut production of Iran. J. Clean. Prod. 2018, 172, 1327-1335. [CrossRef]

2. Pishgar-Komleh, S.H.; Ghahderijani, M.; Sefeedpari, P. Energy consumption and CO 2 emissions analysis of potato production based on different farm size levels in Iran. J. Clean. Prod. 2012, 33, 183-191. [CrossRef]

3. Zahedi, M.; Mondani, F.; Eshghizadeh, H. Analyzing the energy balances of double-cropped cereals in an arid region. Energy Rep. 2015, 1, 43-49. [CrossRef]

4. Raheli, H.; Rezaei, R.M.; Jadidi, M.R.; Mobtaker, H.G. A two-stage DEA model to evaluate sustainability and energy efficiency of tomato production. Inf. Process. Agric. 2017, 4, 342-350. [CrossRef]

5. Zangeneh, M.; Omid, M.; Akram, A. A comparative study on energy use and cost analysis of potato production under different farming technologies in Hamadan province of Iran. Energy 2010, 35, 2927-2933. [CrossRef]

6. Taheri-Rad, A.; Khojastehpour, M.; Rohani, A.; Khoramdel, S.; Nikkhah, A. Energy flow modeling and predicting the yield of Iranian paddy cultivars using artificial neural networks. Energy 2017, 135, 405-412. [CrossRef]

7. Pishgar-Komleh, S.H.; Akram, A.; Keyhani, A.; Raei, M.; Elshout, P.M.F.; Huijbregts, M.A.J.; van Zelm, R. Variability in the carbon footprint of open-field tomato production in Iran-A case study of Alborz and East-Azerbaijan provinces. J. Clean. Prod. 2017, 142, 1510-1517. [CrossRef]

8. Kazemi, H.; Shahbyki, M.; Baghbani, S. Energy analysis for faba bean production: A case study in Golestan province, Iran. Sustain. Prod. Consum. 2015, 3, 15-20. [CrossRef]

9. Pishgar Komleh, S.H.; Keyhani, A.; Rafiee, S.; Sefeedpary, P. Energy use and economic analysis of corn silage production under three cultivated area levels in Tehran province of Iran. Energy 2011, 36, 3335-3341. [CrossRef]

10. Ramedani, Z.; Rafiee, S.; Heidari, M.D. An investigation on energy consumption and sensitivity analysis of soybean production farms. Energy 2011, 36, 6340-6344. [CrossRef]

11. Yousefi, M.; Gazvineh, S. Diesel Fuel Consumption and Energy Use Effiicency of Rainfed Barley Production Systems in Iran. World Appl. Sci. J. 2011, 13, 1375-1379.

12. Anonymous. Detailed Results of the General Agricultural Census of Golestan Province; Iran's Statistics Center: Tehran, Iran, 2014.

13. Kazemi, H.; Kamkar, B.; Lakzaei, S.; Badsar, M.; Shahbyki, M. Energy flow analysis for rice production in different geographical regions of Iran. Energy 2015, 84, 390-396. [CrossRef]

14. Beheshti Tabar, I.; Keyhani, A.; Rafiee, S. Energy balance in Iran's agronomy (1990-2006). Renew. Sustain. Energy Rev. 2010, 14, 849-855. [CrossRef]

15. Banaeian, N.; Zangeneh, M. Study on energy efficiency in corn production of Iran. Energy 2011, 36, 5394-5402. [CrossRef] 
16. Nagy, C. Energy Coefficients for Agriculture Inputs in Western Canada; Centre for Studies in Agriculture, Law and the Environment, University of Saskatchewan: Saskatoon, SK, Canada, 1999.

17. Pimentel, D. Handbook of Energy Utilization in Agriculture; CRC Press: Boca Raton, FL, USA, 1980.

18. Mohammadi, A.; Tabatabaeefar, A.; Shahin, S.; Rafiee, S.; Keyhani, A. Energy use and economical analysis of potato production in Iran a case study: Ardabil province. Energy Convers. Manag. 2008, 49, 3566-3570. [CrossRef]

19. Delshiri, A.; AghaAlikhani, M. Input-output and economic analysis of soybean production in the main cultivation areas in Iran. Afr. J. Agric. Res. 2012, 7, 4894-4899.

20. Houshyar, E.; Kiani, S.; Davoodi, M.J.S. Energy consumption efficiency for corn production utilizing data envelopment analysis (DEA) and analytical hierarchy process (AHP) techniques. Res. Crop. 2012, 13, 754-759.

21. Lorzadeh, S.H.; Mahdavidamghani, A.; Enayatgholizadeh, M.R.; Yousefi, M. Energy Input-Output Analysis for Maize Production Systems in Shooshtar, Iran. Adv. Environ. Biol. 2011, 5, 3641-3644.

22. Naeimeh, S.; Rafiee, S.; Mobli, H.; Mohammadi, A. An analysis of energy use and relation between energy inputs and yield, costs and income of garlic production in Iran. Renew. Energy 2011, 36, 1808-1813.

23. Sahabi, H.; Feizi, H.; Amirmoradi, S. Which crop production system is more efficient in energy use: Wheat or barley? Environ. Dev. Sustain. 2013, 15, 711-721. [CrossRef]

24. Sahabi, H.; Feizi, H.; Karbasi, A. Is saffron more energy and economic efficient than wheat in crop rotation systems in northeast Iran? Sustain. Prod. Consum. 2016, 5, 29-35. [CrossRef]

25. Avval, S.H.M.; Rafiee, S.; Jafari, A.; Mohammadi, A. Improving energy productivity of sunflower production using data envelopment analysis (DEA) approach. J. Sci. Food Agric. 2011, 91, 1885-1892. [CrossRef]

26. Shahin, S.; Jafari, A.; Mobli, H.; Karimi, M. Effect of Farm Size on Energy Ratio for Wheat Production: A Case Study from Ardabil Province of Iran. Am. Eurasian J. Agric. Environ. Sci. 2008, 3, 604-608.

27. Shahan, S.; Jafari, A.; Mobli, H.; Rafiee, S.; Karimi, M. Energy use and economical analysis of wheat production in Iran: A case study from Ardabil province. J. Agric. Technol. 2008, 4, 77-88.

28. Ziaei, S.M.; Mazloumzadeh, S.M.; Jabbary, M. A comparison of energy use and productivity of wheat and barley (case study). J. Saudi Soc. Agric. Sci. 2015, 14, 19-25. [CrossRef]

29. Mohammadi, A.; Omid, M. Economical analysis and relation between energy inputs and yield of greenhouse cucumber production in Iran. Appl. Energy 2010, 87, 191-196. [CrossRef]

30. Yousefi, M.; Damghani, A.M.; Khoramivafa, M. Energy consumption, greenhouse gas emissions and assessment of sustainability index in corn agroecosystems of Iran. Sci. Total Environ. 2014, 493, 330-335. [CrossRef]

31. Taghavifar, H.; Mardani, A. Energy consumption analysis of wheat production in West Azarbayjan utilizing life cycle assessment (LCA). Renew. Energy 2015, 74, 208-213. [CrossRef]

32. ISO14004. Environmental Management Systems: General Guidelines on Principles, Systems and Supporting Techniques; International Organization for Standardization: Geneva, Switzerland, 1996; Volume 14004.

33. Nikkhah, A.; Firouzi, S.; El Haj Assad, M.; Ghnimi, S. Application of analytic hierarchy process to develop a weighting scheme for life cycle assessment of agricultural production. Sci. Total Environ. 2019, 665, 538-545. [CrossRef]

34. Khoshnevisan, B.; Bolandnazar, E.; Shamshirband, S.; Shariati, H.M.; Anuar, N.B.; Mat Kiah, M.L. Decreasing environmental impacts of cropping systems using life cycle assessment (LCA) and multi-objective genetic algorithm. J. Clean. Prod. 2015, 86, 67-77. [CrossRef]

35. Yousefi, M.; Khoramivafa, M.; Mondani, F. Integrated evaluation of energy use, greenhouse gas emissions and global warming potential for sugar beet (Beta vulgaris) agroecosystems in Iran. Atmos. Environ. 2014, 92, 501-505. [CrossRef]

36. Khoshnevisan, B.; Rafiee, S.; Omid, M.; Mousazadeh, H. Applying data envelopment analysis approach to improve energy efficiency and reduce GHG (greenhouse gas) emission of wheat production. Energy 2013, 58, 588-593. [CrossRef]

37. Khoshnevisan, B.; Rafiee, S.; Omid, M.; Yousefi, M.; Movahedi, M. Modeling of energy consumption and GHG (greenhouse gas) emissions in wheat production in Esfahan province of Iran using artificial neural networks. Energy 2013, 52, 333-338. [CrossRef]

38. Khoshnevisan, B.; Shariati, H.M.; Rafiee, S.; Mousazadeh, H. Comparison of energy consumption and GHG emissions of open field and greenhouse strawberry production. Renew. Sustain. Energy Rev. 2014, 29, 316-324. [CrossRef] 
39. Sefeedpari, P.; Ghahderijani, M.; Pishgar-Komleh, S.H. Assessment the effect of wheat farm sizes on energy consumption and CO 2 emission. J. Renew. Sustain. Energy 2013, 5, 023131. [CrossRef]

40. Mobtaker, H.G.; Taki, M.; Salehi, M.; Shahamat, E.Z. Application of nonparametric method to improve energy productivity and CO2 emission for barley production in Iran. Agric. Eng. Int. CIGR J. 2013, 15, 84-93.

41. Nabavi-Pelesaraei, A.; Rafiee, S.; Mohtasebi, S.S.; Hosseinzadeh-Bandbafha, H.; Chau, K.-w. Assessment of optimized pattern in milling factories of rice production based on energy, environmental and economic objectives. Energy 2019, 169, 1259-1273. [CrossRef]

42. Stoellinger, T.; Righetti, T.; Coddington, K. Impact of social cost of carbon analyses in the development of energy projects on federal land. Electr. J. 2016, 29, 63-70. [CrossRef]

43. Mousavi-Avval, S.H.; Rafiee, S.; Jafari, A.; Mohammadi, A. The Functional Relationship Between Energy Inputs and Yield Value of Soybean Production in Iran. Int. J. Green Energy 2011, 8, 398-410. [CrossRef]

44. Banaeian, N.; Zangeneh, M. Estimating production function of walnut production in iran using cobb-douglas method. Agricultura Tropica et Subtropica 2011, 44, 177-189.

45. Banaeian, N.; Zangeneh, M. Modeling energy flow and economic analysis for walnut production in Iran. Res. J. Appl. Sci. Eng. Technol. 2011, 3, 194-201.

46. Troujeni, M.E.; Khojastehpour, M.; Vahedi, A.; Emadi, B. Sensitivity analysis of energy inputs and economic evaluation of pomegranate production in Iran. Inf. Process. Agric. 2018, 5, 114-123. [CrossRef]

47. Banaeian, N.; Omid, M.; Ahmadi, H. Greenhouse strawberry production in Iran, efficient or inefficient in energy. Energy Effic. 2012, 5, 201-209. [CrossRef]

48. Banaeian, N. Do the cattle farms of Iran produce economically efficient or not? Asian J. Agric. Sci. 2011, 3, 142-149.

49. Charnes, A.; Cooper, W.W.; Rhodes, E. Measuring the efficiency of decision making units. Eur. J. Oper. Res. 1978, 2, 429-444. [CrossRef]

50. Banker, R.D.; Charnes, A.; Cooper, W.W. Some models for estimating technical and scale efficiencies in data envelopment analysis. Manag. Sci. 1984, 30, 1078-1092. [CrossRef]

51. Hu, J.L.; Kao, C.H. Efficient energy-saving targets for APEC economies. Energy Policy 2007, 35, 373-382. [CrossRef]

52. Ghasemi Mobtaker, H.; Akram, A.; Keyhani, A.; Mohammadi, A. Optimization of energy required for alfalfa production using data envelopment analysis approach. Energy Sustain. Dev. 2012, 16, 242-248. [CrossRef]

53. Pahlavan, R.; Omid, M.; Akram, A. Energy input-output analysis and application of artificial neural networks for predicting greenhouse basil production. Energy 2012, 37, 171-176. [CrossRef]

54. Naderloo, L.; Alimardani, R.; Omid, M.; Sarmadian, F.; Javadikia, P.; Torabi, M.Y.; Alimardani, F. Application of ANFIS to predict crop yield based on different energy inputs. Measurement 2012, 45, 1406-1413. [CrossRef]

55. Banaeian, N.; Namdari, M. Effect of ownership on energy use efficiency in watermelon farms-A data envelopment analysis approach. Int. J. Renew. Energy Res. 2011, 1, 75-82.

56. Shamshirband, S.; Khoshnevisan, B.; Yousefi, M.; Bolandnazar, E.; Anuar, N.B.; Abdul Wahab, A.W.; Khan, S.U.R. A multi-objective evolutionary algorithm for energy management of agricultural systems-A case study in Iran. Renew. Sustain. Energy Rev. 2015, 44, 457-465. [CrossRef]

57. Moradi, R.; Moghaddam, P.R.; Mansoori, H. Energy use and economical analysis of seedy watermelon production for different irrigation systems in Iran. Energy Rep. 2015, 1, 36-42. [CrossRef]

58. Khoshnevisan, B.; Bolandnazar, E.; Barak, S.; Shamshirband, S.; Maghsoudlou, H.; Altameem, T.A.; Gani, A. A clustering model based on an evolutionary algorithm for better energy use in crop production. Stoch. Environ. Res. Risk Assess. 2015, 29, 1921-1935. [CrossRef]

59. Nabavi-Pelesaraei, A.; Abdi, R.; Rafiee, S.; Bagheri, I. Determination of efficient and inefficient units for watermelon production-a case study: Guilan province of Iran. J. Saudi Soc. Agric. Sci. 2016, 15, 162-170. [CrossRef]

60. Nabavi-Pelesaraei, A.; Abdi, R.; Rafiee, S. Neural network modeling of energy use and greenhouse gas emissions of watermelon production systems. J. Saudi Soc. Agric. Sci. 2016, 15, 38-47. [CrossRef]

61. Mohammadi-Barsari, A.; Firouzi, S.; Aminpanah, H. Energy-use pattern and carbon footprint of rain-fed watermelon production in Iran. Inf. Process. Agric. 2016, 3, 69-75. [CrossRef]

62. Asgharipour, M.R.; Mondani, F.; Riahinia, S. Energy use efficiency and economic analysis of sugar beet production system in Iran: A case study in Khorasan Razavi province. Energy 2012, 44, 1078-1084. [CrossRef]

63. Khanali, M.; Movahedi, M.; Yousefi, M.; Jahangiri, S.; Khoshnevisan, B. Investigating energy balance and carbon footprint in saffron cultivation-A case study in Iran. J. Clean. Prod. 2016, 115, 162-171. [CrossRef] 
64. Firouzi, S.; Vishekaei, M.N.S.; Aminpanah, H. Analysis of energy utilization of peanut-bean intercrop. J. Food Agric. Environ. 2012, 10, 655-658.

65. Mousavi-Avval, S.H.; Rafiee, S.; Sharifi, M.; Hosseinpour, S.; Shah, A. Combined application of Life Cycle Assessment and Adaptive Neuro-Fuzzy Inference System for modeling energy and environmental emissions of oilseed production. Renew. Sustain. Energy Rev. 2017, 78, 807-820. [CrossRef]

66. Mousavi-Avval, S.H.; Rafiee, S.; Sharifi, M.; Hosseinpour, S.; Notarnicola, B.; Tassielli, G.; Renzulli, P.A. Application of multi-objective genetic algorithms for optimization of energy, economics and environmental life cycle assessment in oilseed production. J. Clean. Prod. 2017, 140, 804-815. [CrossRef]

67. Zangeneh, M.; Omid, M.; Akram, A. Assessment of machinery energy ratio in potato production by means of Artificial Neural Network. Afr. J. Agric. Res. 2010, 5, 993-998.

68. Taki, M.; Mahmoudi, A.; Mobtaker, H.G.; Rahbari, H. Energy consumption and modeling of output energy with multilayer feed-forward neural network for corn silage in Iran. Agric. Eng. Int. CIGR J. 2012, 14, $93-101$.

69. Sheikhdavoodi, M.J.; Taki, M.; Monjezi, N. Application of artificial neural networks ANNs to predict energy output for wheat production in Iran. Afr. J. Agric. Res. 2013, 8, 2099-2105.

70. Farjam, A.; Omid, M.; Akram, A.; Fazel Niari, Z. A neural network based modeling and sensitivity analysis of energy inputs for predicting seed and grain corn yields. J. Agric. Sci. Technol. 2014, 16, 767-778.

71. Khoshnevisan, B.; Rafiee, S.; Omid, M.; Yousefi, M. Prediction of environmental indices of Iran wheat production using artificial neural networks. Int. J. Energy Environ. 2013, 4, 339-348.

72. Khoshnevisan, B.; Rafiee, S.; Omid, M.; Mousazadeh, H.; Sefeedpari, P. Prognostication of environmental indices in potato production using artificial neural networks. J. Clean. Prod. 2013, 52, 402-409. [CrossRef]

73. Elhami, B.; Khanali, M.; Akram, A. Combined application of Artificial Neural Networks and life cycle assessment in lentil farming in Iran. Inf. Process. Agric. 2017, 4, 18-32. [CrossRef]

74. Taghavifar, H.; Mardani, A. Prognostication of energy consumption and greenhouse gas (GHG) emissions analysis of apple production in West Azarbayjan of Iran using Artificial Neural Network. J. Clean. Prod. 2015, 87, 159-167. [CrossRef]

75. Nabavi-Pelesaraei, A.; Rafiee, S.; Hosseinzadeh-Bandbafha, H.; Shamshirband, S. Modeling energy consumption and greenhouse gas emissions for kiwifruit production using artificial neural networks. J. Clean. Prod. 2016, 133, 924-931. [CrossRef]

76. Khoshnevisan, B.; Rafiee, S.; Omid, M.; Mousazadeh, H.; Shamshirband, S.; Hamid, S.H.A. Developing a fuzzy clustering model for better energy use in farm management systems. Renew. Sustain. Energy Rev. 2015, 48, 27-34. [CrossRef]

77. Yousefi, M.; Khoshnevisan, B.; Shamshirband, S.; Motamedi, S.; Nasir, M.H.N.M.; Arif, M.; Ahmad, R. Support vector regression methodology for prediction of output energy in rice production. Stoch. Environ. Res. Risk Assess. 2015, 29, 2115-2126. [CrossRef]

78. Rajabi Hamedani, S.; Liaqat, M.; Shamshirband, S.; Al-Razgan, O.S.; Al-Shammari, E.T.; Petković, D. Comparative Study of Soft Computing Methodologies for Energy Input-Output Analysis to Predict Potato Production. Am. J. Potato Res. 2015, 92, 426-434. [CrossRef]

79. Khoshnevisan, B.; Rafiee, S.; Iqbal, J.; Shamshirband, S.; Omid, M.; Anuar, N.B.; Abdul Wahab, A.W. A comparative study between artificial neural networks and adaptive neuro-fuzzy inference systems for modeling energy consumption in greenhouse tomato production: A case study in isfahan province. J. Agric. Sci. Technol. 2015, 17, 49-62.

80. Khoshnevisan, B.; Rafiee, S.; Omid, M.; Mousazadeh, H. Development of an intelligent system based on ANFIS for predicting wheat grain yield on the basis of energy inputs. Inf. Process. Agric. 2014, 1, 14-22. [CrossRef]

81. Nabavi-Pelesaraei, A.; Hosseinzadeh-Bandbafha, H.; Qasemi-Kordkheili, P.; Kouchaki-Penchah, H.; Riahi-Dorcheh, F. Applying optimization techniques to improve of energy efficiency and GHG (greenhouse gas) emissions of wheat production. Energy 2016, 103, 672-678. [CrossRef]

82. Elhami, B.; Akram, A.; Khanali, M. Optimization of energy consumption and environmental impacts of chickpea production using data envelopment analysis (DEA) and multi objective genetic algorithm (MOGA) approaches. Inf. Process. Agric. 2016, 3, 190-205. [CrossRef]

83. Nabavi-Pelesaraei, A.; Rafiee, S.; Mohtasebi, S.S.; Hosseinzadeh-Bandbafha, H.; Chau, K.-w. Energy consumption enhancement and environmental life cycle assessment in paddy production using optimization techniques. J. Clean. Prod. 2017, 162, 571-586. [CrossRef] 
84. The Ministry of Jihad-Agriculture. A Survey on Harvest Area and Production Volume of Farm Crops in 36 Years; The Ministry of Jihad-Agriculture: Tehran, Iran, 2015.

85. Hamedani, S.R.; Shabani, Z.; Rafiee, S. Energy inputs and crop yield relationship in potato production in Hamadan province of Iran. Energy 2011, 36, 2367-2371. [CrossRef]

86. FAO. Food Energy-Methods of Analysis and Conversion Factors; Food and Agriculture Organization of the United Nations: Rome, Italy, 2003.

Publisher's Note: MDPI stays neutral with regard to jurisdictional claims in published maps and institutional affiliations.

(C) 2020 by the authors. Licensee MDPI, Basel, Switzerland. This article is an open access article distributed under the terms and conditions of the Creative Commons Attribution (CC BY) license (http://creativecommons.org/licenses/by/4.0/). 